\title{
Davras Dağı (Isparta) Vejetasyonunun Fitososyolojik ve Fitoekolojik Yönden Araştırılması*
}

\author{
The Phytoecological and Phytosociological Investigation of The Vegetation of Davras \\ Mountain (Isparta)
}

\author{
Coşkun SAĞLAM \\ Selçuk Üniversitesi, Çumra Meslek Yüksek Okulu, Konya
}

Özet: Bu çalışmada, Batı Toroslarda yer alan Davras Dağı'nın vejetasyonu araştırıldı. Vejetasyon Braun-Blanquet metoduna dayalı üç boyutlu ordinasyon tekniğine göre analiz edildi. Araştırma alanında orman, çalı, step ve kaya vejetasyonuna ait 10 bitki birliği tespit edildi. Birlikler ve bağlı oldukları üst birimler aşağıdaki gibidir:

Orman vejetasyonu: Sinıf: Quercetea pubescentis (Oberd 1948) Doing Kraft 1955. Ordo: Querco-Cedretalia libani Barbéro, Loisel ve Quézel 1974. Birlikler: Minuartio globulosi-Juniperetum excelsae Sağlam 2007. Sileno squamigeri-Quercetum cerridis Sağlam 2007. Astragalo oxytropifolii-Pinetum caramanicae Sağlam 2007. Alyans: Lonicero nummulariaefoliaeCedrion libani Quézel, Barbéro ve Akman 1978. Birlikler: Veronico syriaci-Cedretum libani Sağlam 2007. Diantho cibrariiQuercetum vulcanicae Kurt et al. 1996. Sinıf: Quercetea ilicis Br.-B1. 1947. Ordo: Quercetalia ilicis Br.-B1. 1947, Rivaz Martinez 1974. Alyans: Quercion cocciferae Quézel, Barbéro, Akman 1978. Birlik: Hyperico polyphylli-Pinetum brutiae Sağlam 2007.

Çalı vejetasyonu: Sınıf: Quercetea pubescentis (Oberd 1948) Doing Kraft 1955. Ordo: Querco-Cedretalia libani Barbéro, Loisel ve Quézel 1974. Birlik: Astragalo atropurpureus-Quercetum cocciferae Kargığlu ve Tatlı 2005.

Step vejetasyonu: Sınıf: Astragalo-Brometea Quézel 1973. Ordo: Onobrychido armeni-Thymetalia leucostomi Ketenoğlu, Akman, Quézel 1985. Alyans: Phlomido armeniacae-Astragalion microcephali Akman, Ketenoğlu, Quézel, Demirörs 1984. Birlik: Astragaletum prusiano-microcephali sağlam 2007. Ordo: Drabo-Androsacetalia Quézel 1979. Birlik: Astragalo heldreichii-Daphnetum oleoidis Sağlam 2007.

Kaya vejetasyonu: Sınıf: Asplenietea trichomanis (Br.-B1. İn Meier \& B1.-B1. 1934) Oberd 1977. Ordo: Silenetalia odontopetalae Quézel 1973. Alyans: Silenion odontopetalae Quézel 1973. Birlik: Aubrieto canescentis-Omphalodetum luciliea Sağlam 2007.

Anahtar kelimeler: Davras Dağı, Isparta, Ordinasyon, Sinekoloji, Türkiye.

Abstract: In this study, the vegetation of Davras Mountain localized in West Taurus Region had been investigated. The vegetation was analyzed by the three dimensional ordination technique based on the Braun-Blanquet method. Ten associations belonging to the forest, shrub, steppe and rock vegetation types were determined from the investigation area. Associations and their higher units are as follows:

Forest vegetation: Classis: Quercetea pubescentis (Oberd 1948) Doing Kraft 1955. Order: Querco-Cedretalia libani Barbéro, Loisel and Quézel 1974. Associations: Minuartio globulosi-Juniperetum excelsae Sağlam 2007. Sileno squamigeriQuercetum cerridis Sağlam 2007. Astragalo oxytropifolii-Pinetum caramanicae Sağlam 2007.

Alliance: Lonicero nummulariaefoliae-Cedrion libani Quézel, Barbéro and Akman 1978. Associations: Veronico syriaciCedretum libani Sağlam 2007. Diantho cibrarii-Quercetum vulcanicae Kurt et al. 1996. Classis: Quercetea ilicis Br.-B1. 1947. Order: Quercetalia ilicis Br.-B1. 1947, Rivaz Martinez 1974.

Alliance: Querciaon cocciferae Quézel, Barbéro, Akman 1978. Association: Hyperico polyphylli-Pinetum brutiae Sağlam 2007.

Shrub vegetation: Classis: Quercetea pubescentis (Oberd 1948) Doing Kraft 1955. Order: Querco-Cedretalia libani Barbéro, Loisel and Quézel 1974. Association: Astragalo atropurpureus-Quercetum cocciferae Kargığlu and Tatl1 2005.

Steppe Vejetation: Classis: Astragalo-Brometea Quézel 1973. Order: Onobrychido armeni-Thymetalia leucostomi Ketenoğlu, Akman, Quézel 1985. Alliance: Phlomido armeniacae-Astragalion microcephali Akman, Ketenoğlu, Quézel, Demirörs 1984. Association: Astragaletum prusiano-microcephali Sağlam 2007. Order: Drabo-Androsacetalia Quézel 1979. Association: Astragalo heldreichii-Daphnetum oleoidis Sağlam 2007.

\footnotetext{
* Bu çalışmada Selçuk Üniversitesi Bilimsel Araştırma Projeleri Fon Müdürlüğü Tarafından 2002/18 nolu proje ile desteklenen doktora tezinden faydalanılmışır.
} 
Rock Vegetation: Classis: Asplenietea trichomanis (Br.-Bl. İn Meier \& B1.-Bl. 1934) Oberd. 1977. Order: Silenetalia odontopetalae Quézel 1973. Alliance: Silenion odontopetalae Quézel 1973. Association: Aubrieto canescentisOmphalodetum luciliea Sağlam 2007.

Keywords: Davras Mountain, Isparta, Ordination, Synecology, Turkey.

\section{Giriş}

Türkiye'de vejetasyon çalışmaları Anadolu'nun kuzeydoğusunda Handel-Mazzetti (1909) tarafından başlatılmış; batısında Schwarz (1936) ve Czeczott (1938), Orta Anadolu'da ise Krause (1940) gibi yabancı araştırmacılar tarafından sürdürülmüştür (Geven vd., 2009).

$\mathrm{Bu}$ çalışma, Davras Dağı vejetasyonunu fitososyolojik ve fitoekolojik yönden araştırmak amacı ile yapılmıştır. Bu bölgenin vejetasyonu daha önce Braun-Blanquet $(1932,1964)$ metoduna göre çalışılmıştır (Sağlam, 2007). Bitki birliklerine ait vejetasyon tabloları, örnek alanların lokaliteleri ve iklim diyagramları bu çalışmada tekrar verilmemiştir. Bu çalışmada ise araştırma alanındaki bütün vejetasyon tiplerinden alınan örneklik alanlar Bray ve Curtis (1957) tarafından geliştirilen üç boyutlu ordinasyon tekniğine göre yeniden değerlendirilmiştir. Araştırma alanında daha önce Avcı (1991; 1993-1996a,b) ve Kurt vd. (1996) tarafından bazı Fitocoğrafik ve fitososyolojik çalışmalar yapılmıştır.

Zohary (1973), bitki sahalarını ayırdığı haritasında, Akdeniz kıyısında yaygın olan Akdeniz klimax orman sahasını Eğirdir gölü güneyine kadar yayar. Avcı (1993-1996a), inceleme alanımızda yapmış olduğu çalışmada, genel iklim özelliklerinin elverişliliğinin yanı sıra, Eğirdir ve Kovada göllerinin nemlilik açısından meydana getirdiği elverişli durumun, bitki örtüsünün üzerine açık bir şekilde yansıdığını belirtmiştir.

Araştırma alanının seçilmesinde, daha önce benzer bir çalışmanın yapılmamış olması, Akdeniz ve karasal iklimlerinin kesiştiği bir bölgede bulunması, farklı topoğrafik yapısından dolayı çeşitli vejeasyon tiplerine sahip olması, büyük bölümünün Kovada Milli Parkı sınırları içerisinde yer alması etkili olmuştur. Bu çalışma ile Batı Torosların vejetasyonunun bir bölümü daha, fitoekolojik ve fitososyolojik açıdan araştırılmış, çeşitli vejetasyon tiplerine ait bitki birlikleri ve bunların bağlı oldukları sintaksonomik birimler tespit edilmiştir.

Birliklerin floristik yapısını oluşturan türlerin sintaksonomik kategorilere dağılışı ve sosyolojik açıdan yorumlanması son yıllarda yapılan çalışmalardan faydalanılarak yapılmıştır. Bitki birlikleri daha önce yakın bölgelerde yapılmış benzer çalışmalarla karşılaştırılmış, ekolojik, floristik ve sosyolojik benzerlikler belirlenmeye çalışılmıştır. Araştırma alanının tamamı Isparta ili sınırları içerisindedir. Kuzeyinde Isparta-Eğirdir karayolu, güneyinde Isparta-Antalya karayolu ve doğusunda Kovada çayı bulunmaktadır (Şekil 1). Bu alan hem coğrafik hem de fitocoğrafik olarak Akdeniz Bölgesine girer. Türkiye florasına göre yapılan kareleme sistemine göre C3 içinde yer alır. Araştırma alanında Jura-Kretase, Triyas, Paleosen, Eosen, Pliyosen-Pleyistosen yaşlı kaya birimleri bulunur (Şenel, 1997). Araştırma alanında Kahverengi Orman Toprakları Sav Kasabası'nın güneyinden itibaren Isparta-Antalya yolu civarında, Kırmızı Akdeniz Toprakları Davras Dağı ve civarındaki tepelerde, Kırmızımsı Kahverengi Akdeniz Toprakları Eğirdir ve Kovada Gölleri arasında kalan bölgenin batısında ve Yukarıgökdere köyünü de içine alan bölgelerde, Kestanerengi Topraklar ise Küçükhacılar Köyü’ nün kuzeyinde dar bir alanda bulunur (Anonim, 1994).

Araştırma alanı, coğrafi konumu bakımından Akdeniz ve İç Anadolu iklimlerinin kesiştiği bir bölgede yer alsa da doğal bitki örtüsü ve meteorolojik veriler değerlendirildiğinde daha çok Akdeniz ikliminin etkisi altında olduğu görülür. Yıllık ortalama yağış, Isparta' da $551.8 \mathrm{~mm}$, Eğirdir'de 796.1 mm'dir. Gaussen metoduna (Akman, 1990) göre çizilen ombrotermik diyagramlar incelendiğinde yağışların en fazla kış, en az ise yaz mevsiminde olduğu görülür (Sağlam, 2007). Çalışma alanımızın sınırlarında bulunan Isparta ve Eğirdir meteoroloji istasyonlarına düşen yağışın, mevsimlere göre dağılımına baktığımızda, hem Isparta hem de Eğirdir'de KISY şeklinde olup, "Doğu Akdeniz Yağış Rejimi I. Tipi” ne girmektedir. Emberger' in Akdeniz biyoiklim sınıflandırmasına göre hem Isparta hem de Eğirdir kışı soğuk ve az yağışlı biyoiklim tipi özelliği gösterir. 
$\mathrm{Bu}$ çalışmanın, yakın bölgelerde yapılacak yeni vejetasyon çalışmalarına kaynak oluşturarak Türkiye'nin henüz tamamlanamamış olan vejetasyon haritasının oluşturulmasına, son zamanlarda önemi oldukça artan doğal çevremizin tanınma ve korunmasına katkıda bulunmasını ümit ediyorum.

\section{Materyal ve Metot}

Araştırma materyalini 2002-2005 yılları arasında 3 yıl süre ile değişik vejetasyon devrelerine rastlayan Mayıs-Ağustos ayları arasında toplanan bitki örnekleri teşkil etmektedir. Toplanan bitki örneklerinin teşhisi, Davis (1965-1985), Davis vd. (1988), Güner vd. (2000)'nın Türkiye Florası çalışmalarından, Ankara Üniversitesi Fen Fakültesi (ANK) ve Selçuk Üniversitesi Fen Fakültesi Herbaryumu (KNYA)' ndan faydalanılarak yapıldı. Vejetasyonun optimum gelişme gösterdiği devrelerde, homojen alanlardan en küçük alan (minimal area) metoduna göre alınan 101 örnek alan vejetasyon sinıflandırılmasında değerlendirildi. Orman topluluklarına ait sintaksonların sinıflandırılmasında Akman vd. (1978a,b,c, 1979), Quézel (1973), Quézel vd. (1978, 1980), Barbéro ve Quézel (1979) tarafından yapılan çalışmalardan, step topluluklarına ait sintaksonların sinıflandırılmasında Barbéro ve Quézel (1979), Akman vd. (1984, 1985), Quézel vd. (1992), Ketenoğlu vd. (1996), Gemici vd. (1994)'nın çalışmalarından, kaya vejetasyonuna ait sintaksonların sinıflandırılmasında Parolly (1998, 2004), Hein vd. (1998), Gemici vd. (1994)'nın vejetasyon çalışmalarından faydalanıldı. Ayrıca Sorensen (1948)'in benzerlik indisi formülüne göre araştırma alanına yakın yerlerde tanımlanmıș benzer birliklerle floristik kompozisyon benzerliği karşılaştırıldı. İsimlendirmeler fitososyolojik koda göre yapıldı (Weber vd., 2000). Alanın Jeolojisi ile ilgili bilgiler, Maden Tetkik ve Arama Genel Müdürlüğü tarafından hazırlanan 1/100.000 ölçekli Isparta-J11 paftalı jeoloji haritası ve buna ait çeşitli raporlardan faydalanılarak hazırlandı (Şenel, 1997). İklim özellikleri Isparta ili ve Eğirdir ilçesine ait meteoroloji istasyonlarının verilerinden (2002) faydalanılarak yorumlandı. Büyük toprak grupları Köy Hizmetleri Genel Müdürlüğü’nün Isparta İli Arazi Varlığı Raporlarından (1994) yararlanılarak belirlendi. Birliklere ait $0-20 \mathrm{~cm}$ ve $20-40 \mathrm{~cm}$ derinliklerden alınan toprak örneklerinin fiziksel ve kimyasal analizleri Konya Köy Hizmetleri Bölge Müdürlügü Araştırma Laboratuvarı'nda yaptırıldı.

$\mathrm{Bu}$ çalışmada birliklere ait örneklik alanlar Bray ve Curtis (1957) tarafından geliştirilen üç boyutlu ordinasyon tekniğine göre değerlendirildi. Bu tekniğe göre Braun-Blanquet örtüş-bolluk değerleri Van der Maarel (1979)'in ileri sürdüğ̈̈ ordinal değerlere çevrildi. Her örnek alan birbirleriyle $I S=2 x W /(A+B)$ formülü yardımıyla karşılaştırılarak benzerlik emsalleri $(I S)$ bulundu.

$W$ : İki örnek alanda bulunan ortak türlerin ordinal değerlerinin en küçükleri toplamı.

$A$ : Birinci örnek alandaki ordinal değerlerinin tümünün toplamı.

$B$ : İkinci örnek alandaki ordinal değerlerinin tümünün toplamı.

Daha sonra köşegenin üst kısmında kalan kesime benzemezlik değerleri $(I D=100-I S)$ formülüyle hesaplanarak her örnek alanın diğerleriyle olan benzemezlik emsalleri matris tablosundaki yerlerine yazıldı. $x / y$ grafiğinin çizimi için önce $x$ ekseninin uç noktaları bulundu. Uç örnek alanlar hariç diğer örnek alanların $x$ ekseni üzerindeki yerleri $x=\left[L^{2}+(d A)^{2}-(d B)^{2}\right] / 2 L$ formülüyle bulundu.

$L: x$ ekseninin iki ucunu oluşturan örnek alanların $I D$ değeri.

$d A: x$ ekseninin ilk ucunu oluşturan örnek alanın, yerleştirilecek örnek alanla $I D$ değeri.

$d B: x$ ekseninin ikinci ucunu oluşturan örnek alanın yerleştirilecek alanla ID değeri.

$y$ ekseninin ilk uç noktasını bulmak için her örnek alanın $e_{x}^{2}$ değerleri bulundu. Bunun için $e_{x}^{2}=(d A)^{2}-x^{2}$ formülü uygulandı. Elde edilen $e_{x}^{2}$ değerlerinden en yüksek olanı $y$ ekseninin ilk uç (sıfır) noktasını teşkil eden örnek alan olarak alındı. Bundan sonra diğer örnek alanların yerleri $\mathrm{x}$ ekseninde olduğu gibi y ekseninde de $e_{y}^{2}=\left(d A^{\top}\right)^{2}-y^{2}$ formülü ile bulundu.

$x / y$ ordinasyon grafiğinde, birbirinden net olarak ayrılamayan birlikleri daha iyi ayırabilmek için üçüncü bir eksen olan $z$ ekseni oluşturuldu. Bu eksenin ilk uç noktasını teşkil eden örnek alan olarak $x$ ve $y$ eksenlerine en az uyanı seçildi. Bu en az uyum $e_{x}^{2}+e_{y}^{2}$ toplamı en yüksek olan örnek alandır. $z$ ekseninin ilk uç noktasını oluşturan örnek alan ile en yüksek $I D$ değerine sahip olan örnek alan ikinci ucu oluşturur. Diğer örnek alanların yerleri x ve y ekseninde kullanılan formül yardımıyla bulundu. Böylece örneklik alanlara ait $x, y$ ve $z$ ordinatları oluşturuldu (Çizelge 1,2). $x / y$ grafiğinde olduğu gibi $x / z$ grafiği de çizilerek $x / y$ ve $x / z$ grafikleri karşıllaştırıldı. Bu grafiğin çiziminde grafik 
(spss 16.0) proğramı kullanıldı. Birbirine yakın örneklik alanların oluşturduğu kümelerle bitki birlikleri ve bu birliklerin birbirleri ile olan ilişkileri ortaya çıkarıldı (Şekil 2,3,4).

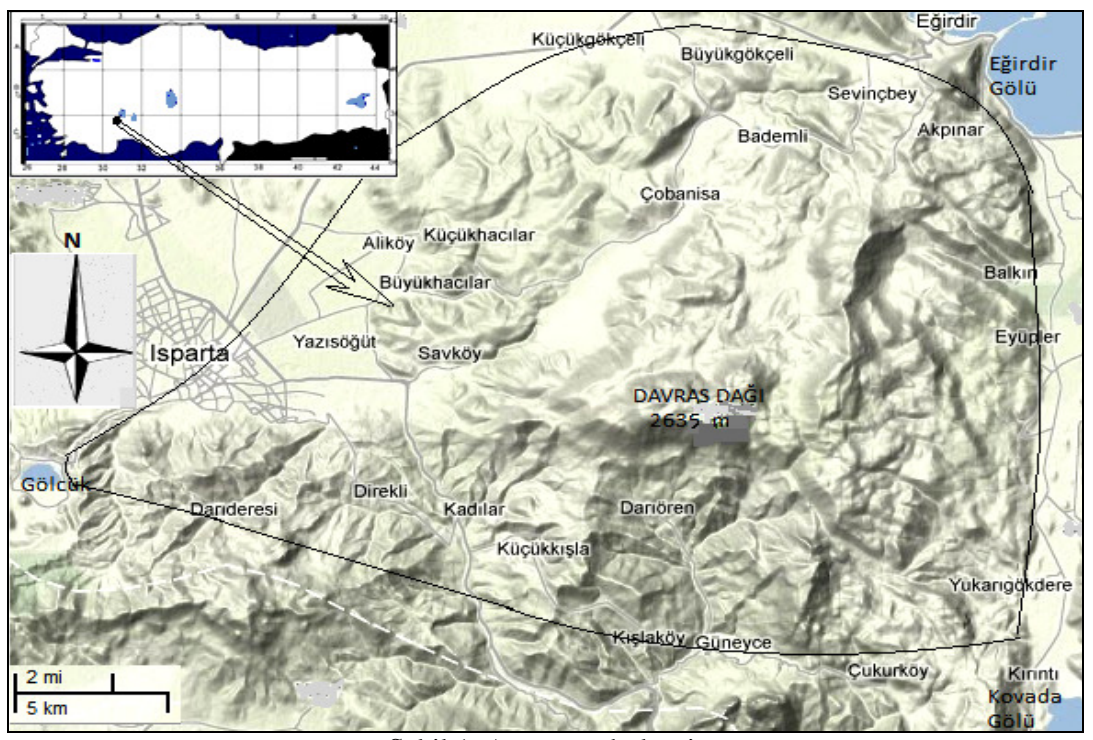

Şekil 1. Araştırma bölgesi.

\section{Bulgular}

Araştırma alanında bulunan Orman vejetasyonunu Pinus nigra subsp. nigra var. caramanica, Cedrus libani, Quercus vulcanica, Quercus cerris var. cerris, Juniperus excelsa ve Pinus brutia toplulukları meydana getirir. Araştırma bölgesinde orman birlikleri 650 ile 1700 m'lik yükseltiler arasında dağılmıştır. Bu yükseklik farkı ve çeşitli topoğrafya, iklim, toprak, yön, eğim gibi ekolojik faktörlerin etkisiyle vejetasyonda da bir tabakalaşma meydana gelmiştir. Bu tabakalaşma arazinin doğusunda, Kovada Gölü’nün güney kısımlarından başlar ve yukarıya doğru devam eder. Pinus brutia 650-1000 m'ler arasında, Quercus cerris var. cerris 1150-1350 m'ler arasinda, Juniperus excelsa 1300-1450 m'ler arasında, Quercus vulcanica 1400-1500 m'ler arasında, Cedus libani 1150-1700 m'ler arasında yayılış gösterir.

Orman vejetasyonuna ait 63 örneklik alan üç boyutlu ordinasyon metoduna göre değerlendirilmiştir. Bu metoda göre ilk önce örneklik alanların benzerlik ve benzemezlik değerleri sonra da $x, y$ ve $z$ ordinasyon değerleri hesaplanmıştır (Çizelge 1).

Çizelge 1. Orman vejetasyonuna ait örneklik alanların $x, y$ ve $z$ ordinasyon değerleri.

\begin{tabular}{|c|c|c|c|c|c|c|c|c|}
\hline Örnek alan no & $\mathrm{IS}$ & $>50 \%$ & $\mathrm{ID}$ & $\mathrm{X}$ & $\mathrm{e}^{2} \mathrm{X}$ & $\mathrm{Y}$ & $\mathrm{e}^{2} \mathrm{Y}$ & $\mathrm{Z}$ \\
\hline 1 & 1040,5 & 9 & 5159,4 & 49,3 & 6575,5 & 9,8 & 1409,3 & 100 \\
\hline 2 & 1218,3 & 10 & 4981,7 & 88,8 & 763,5 & 62,2 & 6131,1 & 49,9 \\
\hline 3 & 1266,2 & 10 & 4933,7 & 91,4 & 652 & 61,2 & 5547,5 & 49,9 \\
\hline 4 & 1105,1 & 10 & 5094,8 & 89,3 & 1050,5 & 61 & 5922,2 & 49,9 \\
\hline 5 & 1148,6 & 10 & 5051,3 & 85,5 & 1153,7 & 67,2 & 5127,4 & 49,9 \\
\hline 6 & 1100,3 & 10 & 5099,7 & 100 & 0 & 59,4 & 6471,6 & 49,9 \\
\hline 7 & 1131,8 & 7 & 5068,1 & 21,2 & 2608,6 & 55,8 & 6529,6 & 50,5 \\
\hline 8 & 1195,6 & 8 & 5004,2 & 23,8 & 3033,5 & 55,5 & 5868,9 & 49,6 \\
\hline 9 & 936,9 & 9 & 5263 & 53,6 & 7127 & 54,9 & 6985,9 & 0 \\
\hline 10 & 1044,3 & 9 & 5155,7 & 55,1 & 6963,9 & 56,3 & 6830,3 & 86,1 \\
\hline 11 & 1122,6 & 10 & 5077,4 & 86 & 1610 & 61,3 & 5515,9 & 50,2 \\
\hline 12 & 920,4 & 10 & 5279,5 & 90,8 & 780,3 & 61,2 & 6254,5 & 50 \\
\hline 13 & 1266,4 & 10 & 4933,6 & 83,9 & 953,1 & 66,9 & 4798 & 49,6 \\
\hline
\end{tabular}




\begin{tabular}{|c|c|c|c|c|c|c|c|c|}
\hline 14 & 1064,8 & 8 & 5135 & 43,4 & 5807,7 & 15,5 & 1820,9 & 33,1 \\
\hline 15 & 955,4 & 8 & 5244,6 & 53,1 & 6725,6 & 10,2 & 1796,9 & 36,1 \\
\hline 16 & 1322,7 & 9 & 4877,3 & 45,7 & 5204,6 & 38,6 & 5006,3 & 47,4 \\
\hline 17 & 1119,3 & 6 & 5080,6 & 50,2 & 5870,5 & 43,6 & 4563,2 & 48,2 \\
\hline 18 & 1449,8 & 11 & 4750,2 & 58 & 5699 & 75,7 & 1648,3 & 48,9 \\
\hline 19 & 1195,8 & 10 & 5004 & 55,5 & 6387 & 74,4 & 2279,2 & 49,5 \\
\hline 20 & 1003,2 & 9 & 5196,7 & 6,2 & 1214,7 & 50 & 7104 & 50,3 \\
\hline 21 & 1200,4 & 10 & 4999,6 & 82,2 & 1397,2 & 67,7 & 5416,7 & 49,7 \\
\hline 22 & 1244,5 & 10 & 4955,5 & 51,7 & 5373,2 & 94,5 & 0 & 50 \\
\hline 23 & 1428,7 & 11 & 4771,3 & 61 & 4798,2 & 89,6 & 1245,5 & 50 \\
\hline 24 & 1491,6 & 11 & 4708,3 & 60 & 4536 & 80 & 961,6 & 49,2 \\
\hline 25 & 1348,3 & 11 & 4851,5 & 67,8 & 4889,9 & 89,5 & 1989,7 & 50 \\
\hline 26 & 1461,8 & 11 & 4738,2 & 67,7 & 4441,7 & 87,3 & 2021,9 & 50 \\
\hline 27 & 1560,8 & 11 & 4639,1 & 50,9 & 4788 & 78 & 1363,6 & 49,4 \\
\hline 28 & 1005,4 & 9 & 5194,5 & 55,3 & 6941,9 & 56,6 & 6796,4 & 84,1 \\
\hline 29 & 929,3 & 9 & 5270,7 & 47 & 6477,2 & 9,9 & 1051,1 & 36,9 \\
\hline 30 & 1326,5 & 7 & 4873,3 & 39,9 & 5616 & 31,2 & 4067,5 & 44,8 \\
\hline 31 & 1103 & 9 & 5096,9 & 50,6 & 6181,8 & 14,4 & 2213,2 & 29,2 \\
\hline 32 & 970,1 & 9 & 5229,9 & 55,7 & 6897,5 & 55,3 & 6941,9 & 82,5 \\
\hline 33 & 955,9 & 9 & 5244 & 53,9 & 7094,7 & 55,3 & 6941,9 & 83,1 \\
\hline 34 & 1022,5 & 9 & 5177,4 & 57,1 & 6739,5 & 58,4 & 6589,4 & 81,4 \\
\hline 35 & 1001,6 & 9 & 5198,4 & 55,4 & 6930,8 & 56,8 & 6773,7 & 81,1 \\
\hline 36 & 1084,3 & 5 & 5115,7 & 5,2 & 1022,7 & 50,6 & 5848,5 & 49,7 \\
\hline 37 & 802,5 & 5* & 5397,5 & 0 & 0 & 55,2 & 6517,7 & 49,8 \\
\hline 38 & 1122,3 & 9 & 5077,6 & 8,1 & 1558,4 & 50,3 & 6287,1 & 49,6 \\
\hline 39 & 1320,1 & 9 & 4879,9 & 47,9 & 5662,2 & 37,5 & 3981,3 & 47,7 \\
\hline 40 & 1028,1 & 9 & 5171,9 & 59,4 & 6471,6 & 59,1 & 6507,1 & 78,2 \\
\hline 41 & 1142,8 & 9 & 5057,1 & 16,8 & 1815,4 & 56,4 & 6442,6 & 50,1 \\
\hline 42 & 1542 & 11 & 4657,8 & 52,5 & 4865 & 81,2 & 1291,9 & 49,9 \\
\hline 43 & 1384,6 & 11 & 4815,4 & 54,8 & 5946,1 & 84 & 1116,1 & 49,5 \\
\hline 44 & 1233,7 & 9 & 4966,2 & 47,1 & 6245,5 & 15 & 1181,2 & 24 \\
\hline 45 & 1124,7 & 9 & 5075,3 & 41,9 & 6308,4 & 8,9 & 1364,7 & 32,6 \\
\hline 46 & 929,8 & 9 & 5270,1 & 47,8 & 7280 & 0 & 0 & 31,2 \\
\hline 47 & 1045,5 & 9 & 5154,3 & 56,1 & 6456,7 & 14,1 & 1582 & 30,8 \\
\hline 48 & 1152,5 & 9 & 5047,5 & 47,1 & 6264 & 16,1 & 1676,7 & 30,2 \\
\hline 49 & 1280,9 & 9 & 4919 & 48,2 & 5687 & 33,9 & 3736,8 & 45,8 \\
\hline 50 & 1343,2 & 9 & 4856,7 & 50,5 & 6135,9 & 32 & 4334,2 & 46,6 \\
\hline 51 & 1370,1 & 8 & 4829,9 & 46,1 & 5636,3 & 38,4 & 4001,4 & 47,3 \\
\hline 52 & 1301,7 & 9 & 4898,3 & 43,4 & 4889,7 & 34,9 & 4897,2 & 47,9 \\
\hline 53 & 1353,9 & 8 & 4846,1 & 43,7 & 5641,9 & 41,8 & 4878,7 & 48,6 \\
\hline 54 & 1330,6 & 8 & 4869,2 & 54,7 & 5994,9 & 31,1 & 4778,4 & 46,6 \\
\hline 55 & 1517,9 & 11 & 4682 & 60 & 5406 & 76,8 & 2004,9 & 50 \\
\hline 56 & 1403,1 & 11 & 4796,8 & 55,2 & 5089 & 82,6 & 1807,6 & 50,5 \\
\hline 57 & 1117 & 7 & 5082,9 & 20,7 & 2498,3 & 58 & 6259,6 & 50,3 \\
\hline 58 & 1055,8 & 7 & 5144,2 & 23,3 & 2938,1 & 53,8 & 6035,8 & 49,7 \\
\hline 59 & 1048,5 & 8 & 5151,5 & 17,2 & 1950,9 & 57,8 & 5932,8 & 49,8 \\
\hline 60 & 1018,8 & 9 & 5181,1 & 57,2 & 6728,1 & 56,8 & 6773,7 & 77 \\
\hline 61 & 919,6 & 9 & 5280,4 & 56,5 & 6807,7 & 54,2 & 7062,3 & 77,4 \\
\hline 62 & 1305,5 & 10 & 4894,5 & 90,2 & 550,1 & 63,4 & 5331,3 & 49,7 \\
\hline 63 & 1151,3 & 10 & 5048,7 & 94,2 & 632,6 & 59,6 & 6447,8 & 49,6 \\
\hline
\end{tabular}


Orman vejetasyonuna ait $x / y$ ordinasyonu (Şekil 2) incelendiğinde 63 örneklik alanın 6 grup oluşturduğu görülmektedir. Bu grupların daha iyi ortaya çıkarılması için $x, y$, ve $z$ verilerinin kullanılmasıyla oluşturulan üç boyutlu ordinasyon grafiği (Şekil 3), floristik yapılarının benzerliğine göre 6 bitki birliği açığa çıkarmıştır.

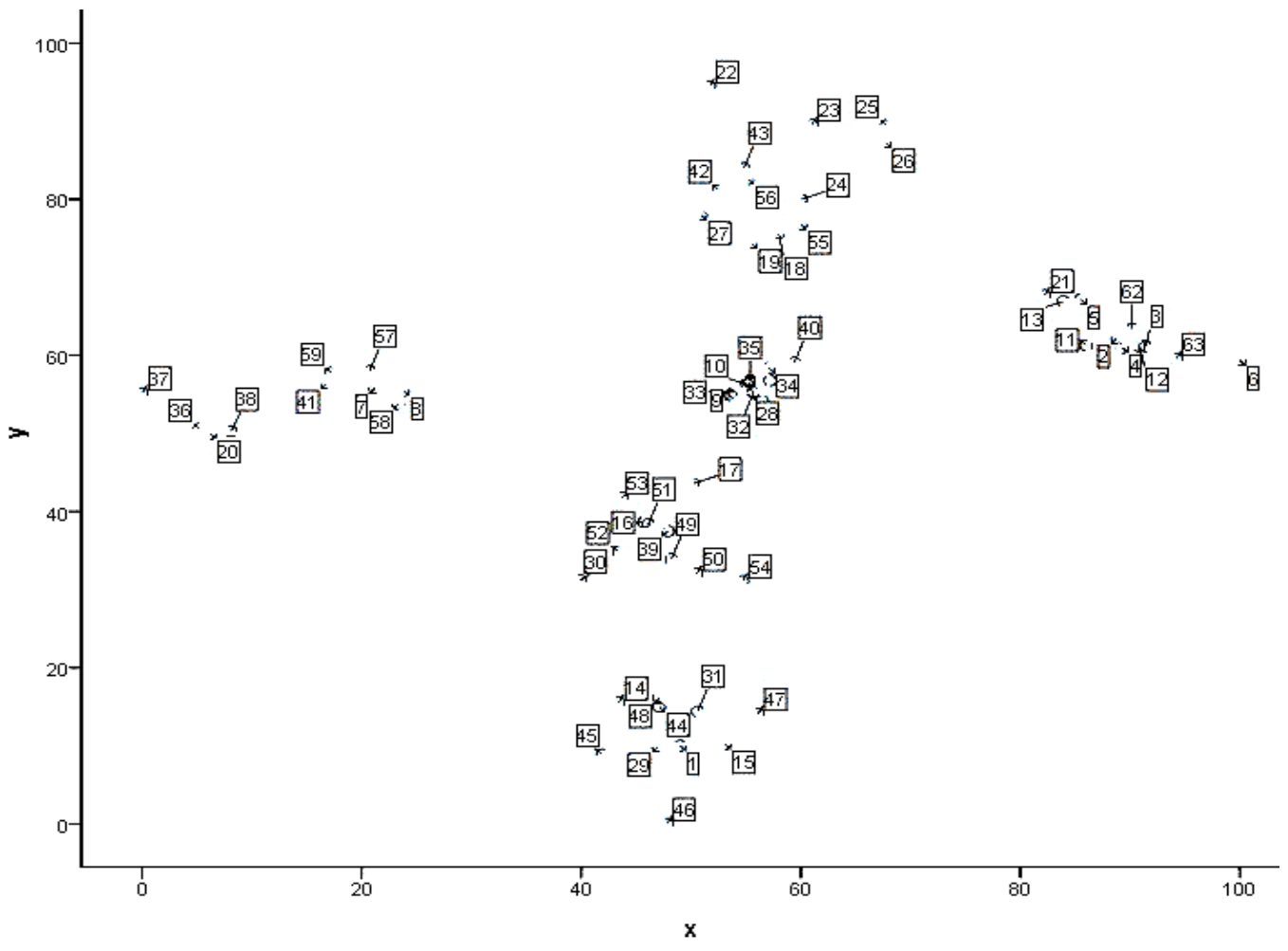

Şekil 2. Orman vejetasyonuna ait örneklik alanların $x / y$ ordinasyonu.

Bu sonuç araştırma alanında daha önce Braun-Blanquet $(1932,1964)$ metodu kullanarak tespit ettiğimiz bitki birliklerini desteklemektedir. Bu grafikte bazı birliklerin aralarındaki mesafenin yakın olması: Çoğunun Davras Dağı'nın doğu yamaçlarında bulunmaları ve sınırlarının çok yakın olması benzer ekolojik koşullarda gelişmelerine ve dolayısıyla ortak türlerin fazla olmasına ve çok sayıda birliğin bir grafikte gösterilmesi gibi sebeplerle açıklanabilir. Oluşan birliklerin adları ve örneklik alan numaraları aşağıdaki gibidir:

\begin{tabular}{|c|c|}
\hline$\underline{\text { Birlik ad} 1}$ & Örneklik alan numaraları \\
\hline Astragalo oxytropifolii-Pinetum caramanicae & $7,8,20,36,37,38,41,57,58,59$ \\
\hline Veronico syriaci-Cedretum libani & $16,17,30,39,49,50,51,52,53,54$ \\
\hline Minuartio globulosi-Juniperetum excelsae & $9,10,28,32,33,34,35,40,60,61$ \\
\hline Hyperico polyphylli-Pinetum brutiae & $2,3,4,5,6,11,12,13,21,62,63$ \\
\hline Sileno squamigeri-Quercetum cerridis & $18,19,22,23,24,25,26,27,42,43,55,56$ \\
\hline Diantho cibrarii-Quercetum vulcanicae & $1,14,15,29,31,44,45,46,47,48$ \\
\hline
\end{tabular}




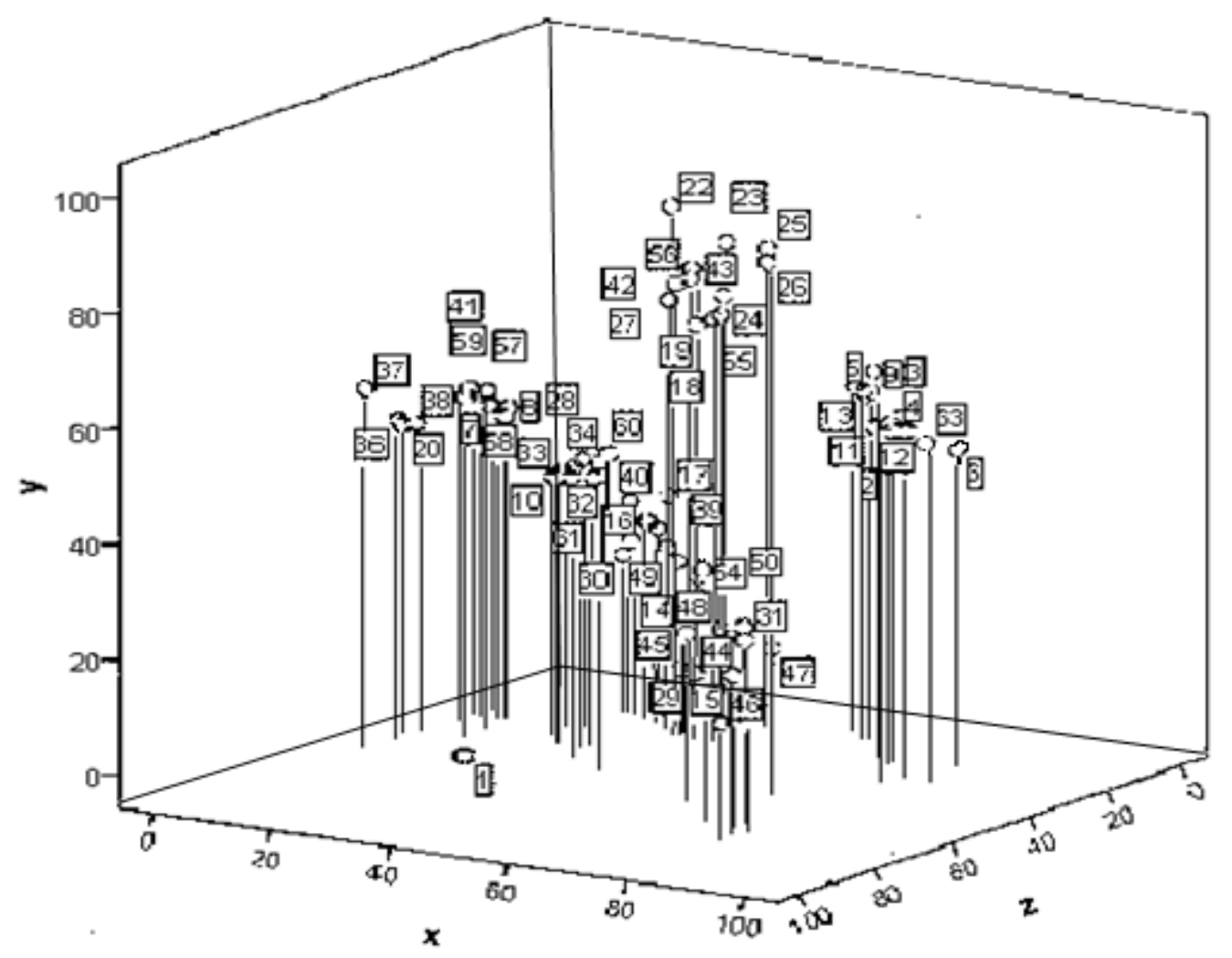

Şekil 3. Araştırma alanının orman vejetasyonuna ait örneklik alanların üç boyutlu ordinasyonu.

Astragalo oxytropifolii-Pinetum caramanicae: Pinus nigra subsp. nigra var. caramanica yurdumuzda genellikle batı Anadolu'da yaygındır ve Pinus brutia kuşağından sonra 1000 m'nin üzerinde yer alır. Tüm Akdeniz Bölgesi’nde Akdeniz Dağ Katı'nın ve aynı zamanda Üst Akdeniz Dağ Katı'nın orman formasyonudur. Birliğin karakteristik ve ayırtedici türü olan Astragalus oxytropifolius endemik bir Iran-Turan elementi olup bat1, güney ve orta Anadolu'da kalker ana kayalar üzerinde yayılış gösterir. Bu birlik 10 örnek alanda tanımlanmıştır (Sağlam 2007). Kırmızımsı kahverengi Akdeniz topraklarında yayılış gösterir. Bu topraklar esas itibarıyla kırmızı Akdeniz ve kahverengi toprakların karışımıdır (Anonim 1994). Birliğe ait örnek alanların toprak analiz sonuçlarına göre, bitki grubunun yaygın olduğu topraklar genellikle hafif asidik ( $\mathrm{pH}$ 6.5-6.6) bir reaksiyon gösterir. Organik madde $\% 1.58, \mathrm{CaCO}_{3} \% 5.4$, fosfor $3.23 \mathrm{~kg} / \mathrm{dek}$, toplam tuz $\% 0.03$, Potasyum $98 \mathrm{~kg} / \mathrm{dek}$ ve elektriksel iletkenliği $0.26-1.30$ arasında olan bu toprakların tekstür sınıfı kumlu-tınlıdır. Birlik, araștırma alanında rakımın 1550-1800 m'lerde ve eğimin $10^{\circ}-45^{0}$ olduğu yamaçlarda bulunur. Ağaç, çalı ve ot olmak üzere üç vejetasyon katından meydana gelmiştir. Pinus nigra subsp. nigra var. caramanica ağaç katının dominant türü olup, aynı zamanda birliğin de ayırtedici karakter türüdür. Ağaç katının genel örtüşü \%65-90, boyu 10-20 m'dir. Çalı katının genel örtüşü \%65-90, boyu 10-20 m'dir. Çalı katının genel örtüşü \%5-25, boyu 0.7-2 m arasında değişmektedir. Çalı katının göze çarpan bitkileri ise Cotoneaster nummularia, Berberis cretica, Juniperus oxycedrus subsp. oxycedrus ve Daphne oleoides'dir. Ot katının genel örtüşü \%2-20 arasında, boyu 20-30 cm olup bu katta step bitkilerinin oranı oldukça fazladır. 
Veronico syriaci-Cedretum libani; Birliğin dominant türü olan Cedrus libani, Türkiye, Lübnan, Kıbrıs ve Kuzey Batı Afrika'da yayılış gösteren bir Akdeniz Dağ elementidir. Türkiye'de özellikle Toros Dağları'nda 1000-2000 m'ler arasında yayılış gösterir. Toros dağları dışında, Anadolu'da tek bir yer olarak Erbaa'nın kuzeyinde bulunur (Akman 1995). Birliğin karakter ve ayırtedici türü olan Veronica syriaca, Özellikle Güney Anadolu Bölgesi’nde yaygın olan endemik bir Doğu Akdeniz elementidir. Birlik, araştırma alanında 1550-1650 m'lerde ve eğimi $10^{0}-35^{\circ}$ arasında değişen 10 örneklik alan ile tanımlanmıştır. Üç tabakalı dikey strüktür gösteren birliğin ağaç katının boyu 7-9 m olup \%65-75 örtüşe sahiptir. Ağaç katında Cedrus libani ile birlikte yer alan türler; Acer hyrcanum subsp. sphaerocaryum, Quercus trojana'dır. Çalı katında bulunan türler; Juniperus oxycedrus subsp. oxycedrus, Lonicera nummulariifolia subsp. glandulifera, Sorbus umbellata var. umbellata, Berberis crataegina, Cotoneaster nummularia, crataegus orientalis var. orientalis ve Fraxinus ornus subsp. cilicica'dır. Veronico syriaci-Cedretum libani birliği, anakayası sert kalker olan kırmızımsı kahverengi Akdeniz topraklarında ve koluviyal topraklarda yayılış gösterir. Birliğe ait örnek alanların toprak analiz sonuçlarına göre; $\mathrm{CaCO}_{3} \% 5.4$, organik madde \%5.28, fosfor 2.72 $\mathrm{kg} / \mathrm{dek}$, toplam tuz \%0.09 ve elektriksel iletkenkiği $0.94-1.40$ olarak bulunmuştur. Potasyum 164 $\mathrm{kg} / \mathrm{dek}$ olup potasyum bakımından oldukça zengindir. Nötr özellik gösteren ( $\mathrm{pH}$ 6.8-6.9) bu toprakların tekstür sınıfı kumlu-tınlıdır.

Minuartio globulosi-Juniperetum excelsae; Jiniperus excelsa, yurdumuzda geniş bir yayllış alanına sahiptir. Anadolu'nun hemen hemen her yerinde orman formasyonlarının tahrip edildiği yerlerde çokça bulunur. Türkiye dışında ise özellikle Iran-Turan fitocoğrafik bölgesinde olmak üzere Balkan Yarımadası, Kırım, Kıbrıs, Batı Suriye, İran ve Afganistan'da geniş yayılış gösterir. Çok farklı yükseltilerde yayılan Juniperus excelsa, Üst Akdeniz katından başlar ve Akdeniz yüksek dağ katına kadar çıkar. Birliğin karateristik ve ayırtedici türü olan Minuartia globulosa kayalık ve taşlık yerlerde yetişen bir Doğu Akdeniz elementi olup Balkanlar, Batı Suriye ve Kıbrıs'ta da yayılış gösterir. Bu birlik araştırma alanında, 1150-1700 m'lerde ve eğimi $15^{\circ}-40^{\circ}$ arasında değişen kayalık ve taşlı yamaçlarda yayılış gösterir. Birlik üç tabakalı dikey bir strüktüre sahiptir. Ağaç katının örtüş durumu \%65-75, Boyu ise 7-9 m'dir. Birlik 10 örneklik alanla tanımlanmıştır. Birlikte bulunan başlıca ağaç ve çalılar, Juniperus excelsa, Quercus coccifera, Styrax officinalis, Berberis crataegina, Juniperus oxycedrus subsp. oxycedrus ve Daphne sericea 'dır. Birlik, anakayası sert kalker olan kırmızımsı kahverengi topraklarda ve koluviyal topraklarda yayılış gösterir. Çalışma alanımızda bulunan bu topraklar aşırı otlatma ve fazla eğimden dolayı kuvvetli erozyona maruz kalmaktadır. Birliğe ait toprak analiz sonuçlarına göre, topraklar çok nötr $(\mathrm{pH} 7.1)$, organik madde ise oldukça düşük oranda bulunur (\%2.85). $\mathrm{CaCO}_{3}$ bakımından oldukça fakir (\%5.4) olup elektriksel iletkenliği 0.69 ile 1.38 arasında değişir. Toplam tuz \%0.02-0.04, Potasyum miktarı 98 kg/dek, Fosfor değeri $2.21 \mathrm{~kg} / \mathrm{dek}$ olan bu toprakların tekstür sınıfı kumlu-tınlıdır.

Hyperico polyphylli-Pinetum brutiae: Pinus brutia, Doğu Akdeniz floristik bölgesinde yayıllıs gösteren mezofanerofit bir çam türüdür. Bugünkü coğrafi yayılış alanı, Güney Ege, Kırım, Kuzey Irak, Batı Suriye, Batı Kafkasya ve Türkiye'dir. Anadolu'nun Akdeniz, Ege ve Marmara Bölgeleri'nde yaygındır. Karadeniz Bölgesi'nde "Karadeniz içi (İntra-pontik) Akdeniz Katı" olarak adlandırılan ve Akdeniz ikliminin etkisi altındaki alanlarda bulunur (Akman 1995). Birliğin karakter ve ayırtedici türleri Hypericum polyphyllum subsp. polyphyllum, Sideritis condensata ve Lotononis genistoides' dir. Hyperico polyphylli-Pinetum brutiae birliği, araştırma alanında yüksekliği 650-1000 m'lerde ve eğimi $10^{0}-35^{0}$ arasında değişen 11 örneklik alan ile tanımlanmıştır. Üç tabakalı dikey bir strüktüre sahip olan birliğin ağaç katının örtüşü \%70-80, boyu 5-25 m'ler arasında değişir. Çalı katının örtüşü \%5-30, boyu 1-2.5 m'dir. Ot katının örtüşü \%5-30 ve ot boyu 10-35 cm'dir. Birlikteki başlıca ağaç, ağaçcık ve çalılar; Pinus brutia, Quercus coccifera, Quercus cerris var. cerris, Quercus trojana, Fontanesia phillyreoides subsp. phillyreoides, Phillyrea latifolia, Pistacia terebinthus subsp. palaestina, Jasminum fruticans, Juniperus oxycedrus subsp. oxycedrus, Crataegus aronia var. minuta, Berberis crataegina, Styrax officinalis, Cistus creticus, Colutea cilicica ve Daphne sericea 'dır. Bu birlik yüksek kireç içeriğe sahip ana madde üzerinde oluşmuş kahverengi orman toprakları'nda bulunur. Bu 
toprakların üzerinde birlik bulunmayanları oldukça sığ olup eğimin fazla olduğu yerlerde erozyon problemi vardır. Üzerinde birliğin bulunduğu toprakların üzeri çam ibrelerinden oluşan $5-10 \mathrm{~cm}$ kalınlığındaki ham humus tabakası ile örtülü olup erozyon çok azdır. Birlik ayrıca kırmızımsı kahverevgi Akdeniz topraklarında da yayılış gösterir. Birlik topraklarının analiz sonuçlarına göre bu topraklar nötr $\left(\mathrm{pH}\right.$ 6.9) olup, organik madde miktarı \%1.58 oranında yer alır. $\mathrm{CaCO}_{3}$ bakımından oldukça fakir (\%5.4) olan bu toprakların toplam tuz oranı \%0.01-0.04, Potasyum miktarı $35 \mathrm{~kg} / \mathrm{dek}$, Fosfor değeri $2.21 \mathrm{~kg} / \mathrm{dek}$ 'dir. Elektriksel iletkenliği 0.35 ile 1.40 arasında değişen bu toprakların tekstür sınıfı kumlu-tınlıdır.

Sileno squamigeri-Quercetum cerridis; Quercus cerris var. cerris, Ülkemizde Orta ve Bat1 Karadeniz, Marmara, Ege, Akdeniz ve İç Anadolu Bölgelerinde yayılış gösterir. Ülkemizin dışında ise İspanya' da yayılış gösterir. Birliğin diğer karakter ve ayırtedici türleri ise Silene squamigera subsp. squamigera ve Phlomis grandiflora var. grandiflora'dır. Birlik, araştırma alanımızda 1150-1400 m'lerde eğimi $10^{\circ}-30^{\circ}$ arasında değişen 12 örneklik alanla tanımlanmıştır. Fizyonomik olarak ağaç, çalı ve ot olmak üzere üç vejetasyon tabakasından oluşur. Ağaç katının boyları 6-14 m, vejetasyon örtüşü \%70-75 arasında değişmektedir. Dominant türü Quercus cerris var. cerris olup, Quercus trojana ve Acer hyrcanum subsp. sphaerocaryum ağaç katının diğer türleridir. Çalı tabakasını oluşturan türler; Styrax officinalis, Paliurus spina-cristi, Juniperus oxycedrus subsp. oxycedrus, Quercus coccifera, Pistacia terebinthus subsp. palaestina, Daphne sericea, Colutea cilicica ve Crataegus aronia var. minuta' dır. Birlik, Kırmızımsı Kahverengi Akdeniz Toprakları üzerinde yayılış gösterir. Birlik topraklarının analiz sonuçlarına göre, topraklar hafif asidik (pH 6.5) reaksiyon gösterir. Organik madde miktarı ise \%4.28 oranında yer alır. $\mathrm{CaCO}_{3}$ bakımından oldukça fakir (\%4.1) olan bu toprakların toplam tuz oranı \%0.05-0.07, Potasyum miktarı $105 \mathrm{~kg} / \mathrm{dek}$, Fosfor değeri $2.72 \mathrm{~kg} / \mathrm{dek}$ 'dir. Elektriksel iletkenliği 0.57 ile 1.9 arasında değişen bu toprakların tekstür sınıfı ise kumlu-tınlıdır. Birlik Kovada Gölü Milli Parkı içerisinde yer aldığı için floristik yapısı oldukça iyi korunmuştur.

Diantho cibrarii-Quercetum vulcanicae Kurt et al. 1996; Endemik bir doğu Akdeniz elementi olan ve kışın yaprağını döken Quercus vulcanica, Şarkikaraağaç-Yenicekale, Tapır ve Gedikli köyleri; Yenişarbademli-Kolankaya, Kıncıraklı, Velledin, Diştaşı ve Üç̧kuyular; Beyşehir-Gölkaya, Üçkuyular ve Suluçayır; Akşehir-Tekke, Savaş ve Çimendere; Afyon-Sultandağı, Derekaya; Kütahya Türkmendağı ve Karaman-Karadağ yörelerinde, rakımı 1100-1600 metreler arasında değișen sahalarda saf ve karışık meşçereler oluşturmaktadır (Gezer vd., 2001). Avcı (1991;1996)'ya göre, kasnak meşesi Eğirdir gölü batısındaki Barla dağının Kuzey yamaçlarında ve Ilgaz dağlarında bulunan Tekçam tepenin güney yamaçlarında da yayılış gösterir. Birliğin karakteristik ve ayırtedici türleri; Quercus vulcanica, Scutellaria rubicunda subsp. brevibracteata, Dianthus cibrarius, Poa speluncarum ve Scaligeria capillifolia'dır. Diantho cibrarii-Quercetum vulcanicae birliği, 1350-1500 m'lerde, eğimi $2^{0}-30^{\circ}$ derece arasında değiş̧en 10 örnek alan ile tanımlanmıştır. Birliğin ağaç katının boyu 10-25 m ve örtüş \%80-85'dir. Ağaç katında Quercus vulcanica ile birlikte yer alan türler; Acer hyrcanum subsp. sphaerocaryum, Cedrus libani ve Quercus trojana'dır. Çalı katının önemli türleri Lonicera etrusca var. etrusca, Berberis crataegina, Daphne sericea ve Fraxinus ornus subsp. cilicica'dır.

Birlik, araştırma alanımızda anakayası sert kalker olan kırmızımsı kahverengi akdeniz topraklarında ve koluviyal topraklarda yayılış gösterir. Birliğe ait örnek alanların toprak analiz sonuçlarına göre; $\mathrm{CaCO}_{3} \% 4.1$, organik madde \%4.50, fosfor $2.21 \mathrm{~kg} / \mathrm{dek}$, toplam tuz \%0.01-0.02, elektriksel iletkenliği $0.28-0.57$, potasyum miktarı $73 \mathrm{~kg} / \mathrm{dek}$ olarak bulunmuştur. Asidik özellik gösteren ( $\mathrm{pH} 4.7-5.0)$ bu toprakların tekstür sınıfı kumlu-tınlıdır.

Çalı vejetasyonu Quercus coccifera topluluklarından oluşur. Bu topluluk Isparta-Eğirdir Karayolu'nun Güney-Doğu kesimlerinde bulunan ve yükseklikleri 1100 m ile 1600 m'ler arasında değişen tepelerde geniş bir alanda yayıllış gösterir. 
Çizelge 2. Çalı, step ve kaya vejetasyonuna ait örneklik alanların $x, y, z$ ordinasyon değerleri.

\begin{tabular}{|c|c|c|c|c|c|c|c|c|}
\hline $\begin{array}{l}\text { Örnek } \\
\text { alan no }\end{array}$ & IS & $>50 \%$ & ID & $X$ & $e^{2} X$ & Y & $e^{2} Y$ & Z \\
\hline 1 & 744,9 & 9 & 2955 & 100 & 0 & 53,9 & 7094,7 & 50,4 \\
\hline 2 & 730,3 & 9 & 2969,7 & 95,6 & 860,6 & 51,6 & 6843,6 & 50,3 \\
\hline 3 & 670,4 & 9 & 3029,6 & 96,3 & 726,3 & 50 & 7500 & 50,1 \\
\hline 4 & 751,8 & 9 & 2948,2 & 93,8 & 1201,5 & 55,8 & 6373,1 & 50,6 \\
\hline 5 & 726,4 & 9 & 2973,4 & 97,1 & 571,5 & 48,8 & 7124,8 & 50,2 \\
\hline 6 & 709,5 & 9 & 2990,4 & 95,5 & 879,7 & 51,4 & 7358 & 50,7 \\
\hline 7 & 700,5 & 9 & 2999,5 & 95,2 & 936,9 & 52,9 & 7201,5 & 50,8 \\
\hline 8 & 709,6 & 9 & 2990,4 & 94,8 & 1012,9 & 54,8 & 6996,9 & 50,6 \\
\hline 9 & 636,6 & 9 & 3063,4 & 95,8 & 822,3 & 51,5 & 7347,7 & 50,4 \\
\hline 10 & 736,6 & 9 & 2963,3 & 94,9 & 993,9 & 50,2 & 6927,8 & 50,2 \\
\hline 11 & 590,7 & 8 & 3109,3 & 53,9 & 7094,7 & 100 & 0 & 61,5 \\
\hline 12 & 688,3 & 8 & 3011,7 & 60 & 6400 & 94,1 & 808 & 62,2 \\
\hline 13 & 575,1 & 7 & 3124,8 & 58,1 & 6624,3 & 86,9 & 2071,9 & 75,5 \\
\hline 14 & 606,5 & 6 & 3093,5 & 58,6 & 6566 & 86,4 & 2535 & 0 \\
\hline 15 & 714,5 & 9 & 2985,5 & 63,8 & 5929,5 & 93,1 & 1332,3 & 75,4 \\
\hline 16 & 744,8 & 9 & 2955,2 & 61,7 & 6193,1 & 90,4 & 1510,4 & 71 \\
\hline 17 & 711,4 & 8 & 2988,6 & 63,5 & 5967,7 & 90,8 & 1418,2 & 56,5 \\
\hline 18 & 656,5 & 8 & 3043,5 & 57,8 & 6659,1 & 90,1 & 1881,9 & 64,2 \\
\hline 19 & 692 & 9 & 3008 & 58,2 & 6612,7 & 95,3 & 917,9 & 69,2 \\
\hline 20 & 678,7 & 8 & 3021,3 & 59,6 & 6447,8 & 90,7 & 1124,4 & 64,5 \\
\hline 21 & 703,9 & 9 & 2996 & 50 & 7500 & 0 & 0 & 100 \\
\hline 22 & 579 & 9 & 3120,8 & 47,2 & 7220 & 8,5 & 1633,4 & 32,7 \\
\hline 23 & 725,2 & 9 & 2974,7 & 52,4 & 7254,2 & 9,3 & 1062,7 & 28,1 \\
\hline 24 & 738,4 & 9 & 2961,4 & 52,3 & 7264,7 & 3,1 & 615,3 & 21,8 \\
\hline 25 & 673,4 & 9 & 3026,6 & 52,4 & 7254,2 & 5 & 979,8 & 26,6 \\
\hline 26 & 654,9 & 9 & 3044,9 & 50 & 7500 & 1,8 & 369,2 & 17,4 \\
\hline 27 & 765,7 & 9 & 2934,3 & 50 & 6967,2 & 8,2 & 791,2 & 25 \\
\hline 28 & 726 & 9 & 2973,9 & 50 & 7500 & 3,6 & 710,6 & 23,2 \\
\hline 29 & 727,3 & 9 & 2972,5 & 52,4 & 7254,2 & 11,8 & 1501 & 32,2 \\
\hline 30 & 607,9 & 9 & 3092,1 & 50 & 7500 & 7,7 & 1485,1 & 31,5 \\
\hline 31 & 579,3 & 7 & 3120,6 & 4,2 & 835 & 39,2 & 6313,3 & 49,3 \\
\hline 32 & 570,5 & 7 & 3129,4 & 6 & 1168 & 39,3 & 6323,2 & 49,3 \\
\hline 33 & 533,6 & 7 & 3166,3 & 4,2 & 835 & 43,4 & 6802,6 & 49,7 \\
\hline 34 & 525,7 & 7 & 3174,2 & 9,7 & 1859,5 & 40,7 & 6497,5 & 49,5 \\
\hline 35 & 469,5 & 7* & 3230,4 & 0 & 0 & 50 & 7500 & 50 \\
\hline 36 & 588,5 & 7 & 3111,3 & 6 & 1168 & 39,3 & 6323,2 & 49,3 \\
\hline 37 & 573,3 & 7 & 3126,7 & 8 & 1536 & 37,4 & 6100,7 & 49,1 \\
\hline 38 & 546,6 & 7 & 3153,2 & 2,8 & 568,1 & 43,5 & 6812,6 & 49,7 \\
\hline
\end{tabular}

Step vejetasyonunu Davras Dağı'nın kuzey-Batı yamaçlarında 1300-2300 m'ler arasında yayılış gösteren Astragalus microcephalus ve Daphne oleoides subsp. oleoides bitki toplulukları meydana getirir (Şekil 4). Ayrıca Davras Kayak Merkezi'nin kuzeyinde 1800 m'lerde bulunan düzlüklerde Marrubium globosum subsp. globosum bitki topluluğu bulunur. Fakat kayak merkezine yakınlığından dolayı turistik amaçlı tesislerin yapılması ve yaylacılık faaliyetlerinden dolayı aşırı tahrip edilmiştir. Bu yüzden geniş bir alanda saf olarak yaygın değildir. Kozağacı Yaylasında ise Artemisia campestris bitki topluluğu mevcuttur. Bu alanda da yaylacılık faaliyetlerinden dolayı aşırı derecede keçi otlatması vardır. Keçiler bu bitkiyi yemedikleri için dominant hale geçmiştir. Fakat 
otlatma ortadan kalkınca bu durumun değişebileceği düşünülerek bu bitki topluluğundan alınan örneklik alanlar değerlendirmeye alınmamıştır.

Kaya vejetasyonunu ise Davras Dağı'nın Kuzey-Batı kesimlerinde ve zirvesine yakın yerlerde 2380-2500 m'ler arasında yayılış gösteren Omphalodes luciliae subsp. luciliae bitki topluluğu oluşturur.

Çalı, Step ve kaya vejetasyonuna ait 38 örneklik alanın $x, y$ ve $z$ ordinat değerleri hesaplanmıştır (Çizelge 2). Bu değerlere ait üç boyutlu ordinasyon grafiği oluşturulmuştur (Şekil 4). 38 örneklik alan floristik benzerliklerine göre net bir şekilde 4 grup oluşturmuştur. Bu şekilde 4 bitki birliğinin net bir şekilde ayrılmasının sebebi, yükseklik farkından dolayı farklı ekolojik koşulların mevcut olması ve buna bağlı olarak floristik benzerliğin oldukça az olmasıdır.

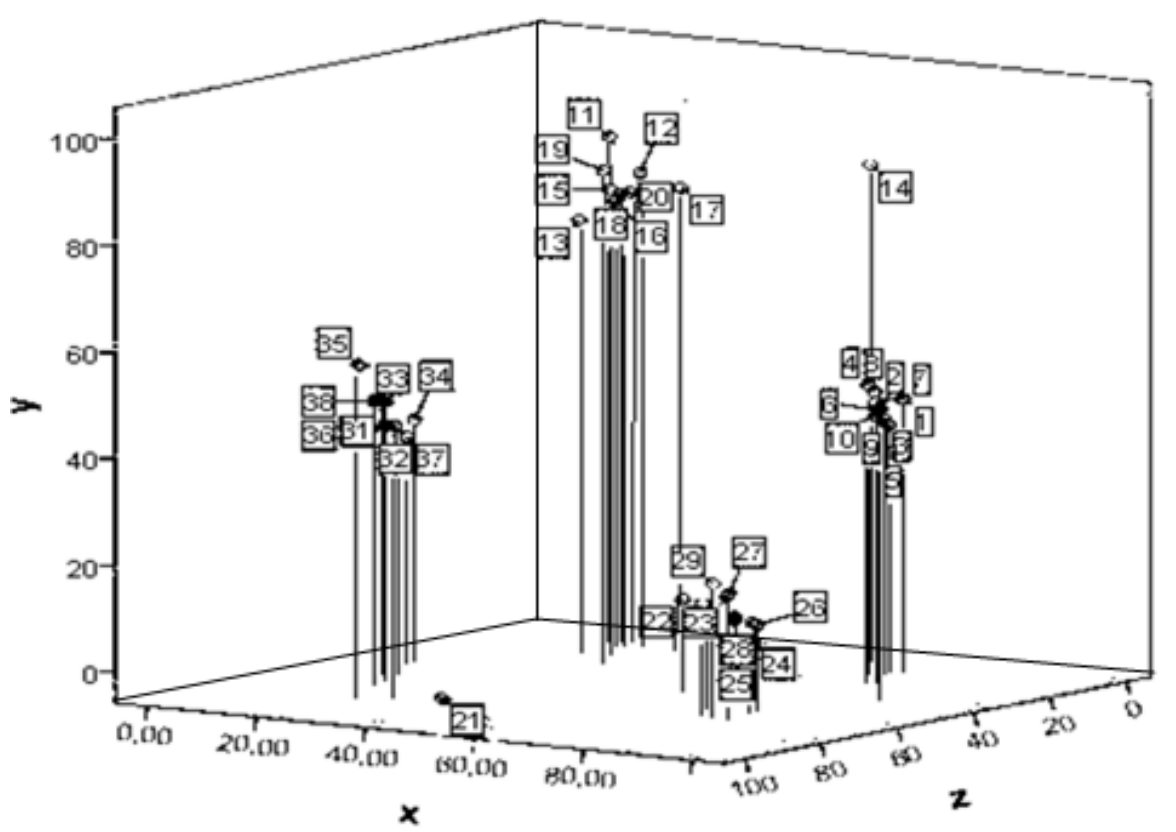

Şekil 4. Çalı, step ve kaya vejetasyonuna ait örneklik alanların üç boyutlu ordinasyonu.

Üç boyutlu ordinasyon grafiğine göre oluşan bitki birliklerinin adları ve örneklik alan numaraları aşağıdaki gibidir:

\begin{tabular}{lc} 
Birliğin adı & Örnekli alan numaraları \\
\cline { 2 - 2 } Astragalo atropurpureus-Quercetum cocciferae & $1-10$ \\
Astragaletum prusiano-microcephali & $11-20$ \\
Astragalo heldreichii-Daphnetum oleoidis & $21-30$ \\
Aubrieto canescentis-Omphalodetum luciliea & $31-38$
\end{tabular}

Astragalo atropurpureus-Quercetum cocciferae; Quercus coccifera, Akdeniz ülkelerinin hepsinde yayılış gösteren herdem yeşil kserofit bir çalıdır. Tipik bir maki elemanı olan bu tür yurdumuzda başlıca kuzeybatı, batı ve güney Anadolu'da, Adalarda ve Kuzey Anadolu'da yaygındır. Birliğin diğer karakter ve ayırtedici türleri, Micromeria myrtifolia ve Astragalus campylosema subsp. atropurpureus'dur. Birlik, araştırma alanında eğimi $10^{0}-40^{0}$, yüksekliği 1050-1500 m'ler arasında değişen 10 örneklik alanda tanımlanmıştır. Çalı ve ot katı olmak üzere iki tabakalı dikey bir strüktür göstermektedir. Çalı katının boyu 1-2.5 m, örtüşü \%70-75' dir. Ot katının boyu 20-35 cm, ot örtüş \%25-50'dir. Birlikte yer alan başlıca çalılar, Quercus coccifera, Berberis cretica, Cotoneaster nummularia, Styrax officinalis, Juniprus oxycedrus subsp. oxycedrus, Pistacia terebinthus, Jasminum 
fruticans, Daphne sericea, Lonicera etrusca var. etrusca, Colutea cilicica, Rhus coriaria' dir. Birlik, araştırma alanında koluviyal topraklarda ve kırmızı Akdeniz topraklarında yayılış gösterir. Bu toprakların üst yüzeyi organik madde yönünden fakirdir. Topraklar ana maddenin özelliğini oldukça fazla yansitırlar. Birliğin homojen olarak yayılış gösterdiği yerlerden alınan toprakların analiz sonuçlarına göre, $\mathrm{CaCO}_{3} 4.1-5.4$, organik madde $\% 4.50$, fosfor $2.72 \mathrm{~kg} / \mathrm{dek}$, toplam tuz $\% 0.01-0,05$ ve elektriksel iletkenlik 0.26-1.30 olarak bulunmuştur. Potasyum miktarı $143 \mathrm{~kg} / \mathrm{dek}$ olup potasyum bakımından oldukça zengindir. Nötr özellik gösteren (pH 7.0 ) bu toprakların tekstür sınıfı kumlutınlıdır.

Astragaletum prusiano-microcephali; Birliğin dominant türü olan Astragalus microcephalus, özellikle İç Anadolu' da steplerde yayılış gösteren kamefit dikenli bir Iran-Turan elementidir. Karakter türü olan Astragalus prusianus Kuzey ve Güney Batı Anadolu'da yayılış gösteren endemik bir Doğu Akdeniz elementidir. Silene lydia ise Doğu Akdeniz elementidir. Astragaletum prusiano-microcephali birliği, Küçük Davras Dağı'nın Güney eteklerinde ve Isparta'nın güney batısında eğimi $5^{0}-40^{\circ}$, yüksekliği 1450-1700 m'ler arasında değişen alanlarda yayılış gösterir. Topluluğa Paronychia kurdica subsp. kurdica, Ziziphora tenuior, Bromus tectorum türleri yoğun olarak katılmaktadır. 10 örnek alanda tanımlanan ve sadece ot katından oluşan tek tabakalı bir strüktür gösteren bu birliğin genel örtüşü \% 70-90, boyu ise 10-80 cm arasında değişmektedir. Birlik, Küçük Davras dağında kalker içeriğe sahip ana madde üzerinde oluşmuş Kahverengi Orman Topraklarında, Isparta'nın güney batısında ise ana maddesi volkanik tüf ve kül olan Regosol Topraklar üzerinde bulunur. Birliğin homojen olarak yayılış gösterdiği yerlerden alınan toprakların fiziksel ve kimyasal analiz sonuçlarına göre, $\mathrm{CaCO}_{3} \% 2.25$ ve $\% 5.4$, organik madde $\% 0.92$, fosfor $2.02 \mathrm{~kg} / \mathrm{dek}$, toplam tuz $\% 0.01$, potasyum $44 \mathrm{~kg} / \mathrm{dek}$, pH değeri nötr (6.7-7.2) olarak bulunmuştur. Elektriksel iletkenliği 0.39 olan bu toprakların tekstür sinıfı 0-20 cm derinliklerde kumlu-tınlı, 20-40 cm derinliklerde kumludur.

Astragalo heldreichii-Daphnetum oleoidis; Daphne oleoides subsp. oleoides, İç Anadolu ve yakın çevresinde, Avrupa'nın güneyinde, Kuzeybatı Avrupa ve Lübnan'da yayılış gösteren nanofanerofit bir bitkidir. Birliğin karakter ve ayırtedici türleri aşağıdaki gibidir;

Daphne oleoides subsp. oleoides Doğu Akdeniz dağ elementi

Astragalus heldreichii

Endemik.

Asyneuma compactum

Endemik.

Tragopogon olympicus

Endemik, Doğu Akdeniz dağ elementi.

Valeriana oligantha

Endemik, Doğu Akdeniz dağ elementi.

Asperula stricta subsp. monticola

Endemik, Doğu Akdeniz dağ elementi.

Paronychia davisii

Endemik, Doğu Akdeniz dağ elementi.

Astragalo heldreichii-Daphnetum oleoidis birliği, Davras Dağı'nın batı ve güneybatı yamaçlarında kalker anakayadan oluşmuş kırmızı Akdeniz toprakları üzerinde yayılış gösterir. Bünyesinde Daphne oleoides subsp. oleoides'ten başka hiçbir çalı ve odunsu bitki bulunmaz. Bu yüzden iki tabakalı dikey bir strüktür gösterir. Birliğin yayılış gösterdiği alanların eğimi $30^{\circ}-50^{\circ}$, yüksekliği 2020-2300 m'ler arasında değişir. 10 örneklik alanda tanımladığımız bu birliğin örtüş durumu \%50-70, ot boyu 5-40 cm arasında değişmektedir. Birliğin bulunduğu yüksekliğe ve bünyesindeki bitkilere bakıldığı zaman diğer step birliklerinden farklı olarak yüksek dağ stebi özelliği taşır. Rakım 2030 m'den yukarı doğru çıktıkça eğim artmakta ve aşırı erozyondan dolayı toprak miktarı azalmaktadır. Bundan dolayı step bitkilerinin sayısı azalmakta ve kaya vejetasyonuna ait bitkiler birliğin yapısına katılmaktadır. Birliğin homojen olarak yayılış gösterdiği yerlerden alınan toprakların fiziksel ve kimyasal analiz sonuçlarına göre, $\mathrm{CaCO}_{3} \% 5.7$, organik madde \%1.53, fosfor $2.08 \mathrm{~kg} / \mathrm{dek}$, toplam tuz \% 0.05-0.06, potasyum $70 \mathrm{~kg} / \mathrm{dek}$, pH nötr (7.3), elektriksel iletkenlik 1.301.87 olarak bulunmuştur. Bu toprakların tekstür sınıfı 0-20 m'lerde kumlu-tınlı, 20-40 m'lerde tınlıdır.

Aubrieto canescentis-Omphalodetum luciliea; Omphalodes luciliae subsp. luciliae, Güneybat1 Anadolu'da yayılış gösteren endemik bir Doğu Akdeniz elementidir. Birliğin karakter ve ayırtedici türlerinin tamamı endemik olup aşağıdaki gibidir: 
Omphalodes luciliae subsp. luciliae

Aubrieta canescens subsp. canescens

Muscari bourgaei

Arenaria ledebouriana var. pauciflora
Endemik Doğu Akdeniz elementi.

Endemik.

Endemik Doğu Akdeniz elementi.

Endemik.

güneybatı'ya bakan yüzeylerinde kalker kayalıklarda yayılış gösterir. Bu kayalıkların eğimi $70^{\circ}$ $90^{\circ}$, rakımı 2350-2500 m'dir. Uçurum kayaların çatlaklarında ve çukurlarında birikmiş topraklar üzerinde gelişmiş olan bu bitkilerin tamamı otsu formdadır. 8 örneklik alanla tanımladığımız birliğin ot örtüşü \% 5-10, Ot boyu 5-30 cm'dir. Birliğin homojen olarak yayılış gösterdiği yerlerden alınan toprakların fiziksel ve kimyasal analiz sonuçlarına göre, $\mathrm{CaCO}_{3} \% 5.2$, organik madde $\% 1.08$, fosfor $2.38 \mathrm{~kg} / \mathrm{dek}$, toplam tuz \% 0.05 , potasyum $120 \mathrm{~kg} / \mathrm{dek}, \mathrm{pH}$ nötr (7.1), elektriksel iletkenliği 1.56, tekstür sınıfı kumlu-tınlıdır.

\section{Tartışma ve Sonuç}

Araştırma alanı çıplak kaya ve molozlardan, bol humuslu orman alanlarına kadar farklı karakterlere sahip çok sayıda habitatları ihtiva etmektedir. Denizden yüksekliğinin $600 \mathrm{~m}$ 'den 2635 m'ye kadar çıkması ve engebeli bir arazi yapısına sahip olması ayrıca habitatlar üzerinde hem Akdeniz hem de İç Anadolu iklimlerinin çakışması, bölge vejetasyonunda çeşitliliğin artmasına sebep olmuştur. Alanımızda tanımlanan bazı birliklerin dominant bitkileri farklı coğrafik bölgelerde yayılış göstermektedir. Aynı dominant türün farklı coğrafik bölgelerdeki formasyonları, floristik kompozisyon yönünden farklılık göstermektedir. $\mathrm{Bu}$ durum dominant bitkisi aynı olan farklı sintaksonlar doğurmaktadır. Birliklerin yalnızca dominant bitkiye dayalı isimlendirilmesi ileride karışıklığa neden olabileceğinden bu karışıklığın önlenmesi için isimlendirmede dominant bitki ile birlikte bölgesel veya endemik türler kullanılmıştır. Araştırma alanmızda tanımlanan bitki birlikleri son yıllarda Doğu Akdeniz Bölgesi'nde ve Kuzeybatı Anadolu Bölgesi'nde yapılan çalışmaların ışığı altında aşağıdaki fitososyolojik birimler içerisinde değerlendirilmiştir;

Quercetea pubescentis sınıfı (Oberd, 1948) Doing Kraft 1955; Genellikle Akdeniz çevresinde egemen olan bir sınıftır. Ancak Kuzey Anadolu'da Avrupa-Sibirya biyocoğrafya kökenli olan Karadeniz bölgesine kadar yayılır. Bu sınıf coğrafi duruma göre iki ordoya ayrılır: QuercoCarpinetalia orientalis Quézel, Barbéro, Akman 1980 ve Querco-Cedretalia libani Barbéro, Loisel ve Quézel 1977.

Querco-Cedretalia libani Barbéro, Loisel ve Quézel 1977 ordosu, Querco-Carpinetalia orientalis ordosu dışında, Üst Akdeniz ile Akdeniz Dağ Katı'nda yayılış gösteren orman gruplarını içine alır. Torosların tüm orman formasyonları ile Batı Anadolu'daki Pinus nigra ve bazı Pinus brutia orman toplulukları bu ordo içine dahil edilebilir. Karadeniz bölgesinde bulunmayan bu ordo İç Anadolu'nun biraz daha doğusunda da bulunur. Biyoiklim bakımından bu ordo az yağışlı ve yağışlı, soğuk Akdeniz iklimine bağlanır (Akman 1995).

Quercetea ilicis Br.-B1. 1947; Bu sınıf Yunanistan'dan yakın doğuya kadar doğu Akdeniz havzasının kıyı şeridi boyunca oldukça iyi gelişmiş olup, çok sayıda kserofil ve yaprak döken orman türlerinden meydana gelir. Yurdumuzda ise Güney Anadolu, Ege Bölgesi, Kuzeybatı Anadolu ve Karadeniz Bölgesi'nin Akdeniz iklimi gösteren bazı kesimlerinin vejetasyonunu içine alır. Bu sınıf, maki topluluklarının yanısıra Pinus pinea, Pinus brutia ve Cupressus sempervirens orman formasyonlarını da ihtiva etmektedir. Sınıf iki ordoya ayrılmaktadır: Pistacio-Rhamnetalia alaterni Rivaz Martinez 1974 ve Quercetalia ilicis Br.-Bl. 1947, Rivaz Martinez 1974.

Astragalo-Brometea Quézel 1973; Bu sınıf Anadolu'da özellikle Toros dağlarında tanımlanmış olup yastık teşkil eden dikenli kamefitler ile benzer biyolojik tipten oluşan bitkileri içine alır. Bu sınıf İç Anadolu'daki step topluluklarını içine alan Onobrychido armeni-Thymetalia leucostomi ordosu ve Torosların aşırı rüzgara maruz kalan alpin ve subalpin katlarındaki bitki birliklerini içine alan Drabo-Androsacetalia ordosu ile temsil edilir. İç Anadolu'nun kuzey yarısında gerçekleştirilen çalışmaların 1 şı̆̆ altında oluşturulan Onobrychido armeni-Thymetalia leucostomi 
ordosu Kuzey Anadolu'da dört (Akman vd., 1985), İç Anadolu'nun güneybatısında bir alyans (Ketenoğlu vd., 1996) içermektedir.

Asplenietea trichomanis Oberd 1977; Bu sınıf Torosların yüksek dağlarındaki kayaların yüzeylerinde, çatlaklarında ve çukurlarında gelişmiş kosmofitik vejetasyonları içine alır. Bu sınıf Türkiye'de iki ordo ile temsil edilir. Bunlar; Kuzeybatı, Batı ve Güney Anadolu'nun kaya vejetasyonunu içine alan Silenetalia odontopetalae ordosu ile Avrupa-Sibirya fitocoğrafik bölgesinin kaya vejetasyonunu içine alan Androsacetalia multiflorae ordosudur. Silenetalia odontopetalae ordosu alt1 alyans ile temsil edilir (Parolly, 1998, 2004). Bu alyanslardan Silenion odontopetalae Quézel 1973, araştırma alanımızın da bulunduğu batı Torosları içine alır.

Pinus nigra birliği; Akman vd. (1979), yurdumuzdaki karaçam ormanlarını fitososyolojik yönden kuzeybatı Anadolu'nun karaçam ormanları, batı Anadolu'nun karaçam ormanları, güney Anadolu'da Amanos ve Toros dağlarının karaçam ormanları şeklinde gruplandırmışlardır.

Quézel vd. (1980), karaçam ormanlarını çok değişik floristik yapıya sahip olduklarından Quercetea pubescentis sinıfının Querco-Cedretalia libani ve Querco-Carpinetalia orientalis ordolarına bağlamışlardır. Akman vd. (1979)'na göre Karaçam ormanları Toros dağlarında yağı̧̧ yönünden çok değişkendir. Yağışın $1000 \mathrm{~mm}$ 'nin üzerinde hatta $1500 \mathrm{~mm}$ olduğu yerlerde bazen de yağışın 400-500 mm olduğu Torosların Anadolu'ya bakan yamaçlarında yaygındırlar. Kuzeybatı Anadolu karaçam ormanları Querco-Carpinetalia orientalis ordosuna, Toroslar'daki karaçam ormanları ise Querco-Cedretalia libani ordosuna girmektedir.

Araştırma bölgemizde ise yıllık yağışın ortalama 550-800 mm arasında değiştiği kışı soğuk, az yă̆ışlı Akdeniz ikliminin hüküm sürdüğü yerlerde Özellikle Küçük Davras Dağı'nın kuzeyinde yayılış gösterir. Tanımladığımız bu birlik Quercetea pubescentis sınıfının Querco-Cedretalia libani ordosuna bağlanmıştır. Birlik bilinçsiz kesim ve aşırı otlatma gibi biyotik faktörlerin etkisi altında kalarak tahrip edilmiş, formasyonun normal strüktür ve floristik kompozisyonu bozulmuştur. $\mathrm{Bu}$ sebepten dolayı orman altı florasında bol miktarda step bitkileri bulunmaktadır. Pinus nigra birliği daha önce yurdumuzun birçok yerinde çeşitli araştırıcılar tarafından tanımlanmıştır. Bunlardan araştırma alanına en yakın olanları; Sultan Dağlarında ve Seydişehir Maden bölgesinde (Ocakverdi, 1982, 1987), Yandağ'da (Kargıŏlu ve Tatlı, 1994), Barla Dağı'nda (Bekat, 1987) ve Dedegöl Dağı'nda (Serin, 1996) yapılan çalışmalardır. Bulgularımızla araştırma alanına yakın yerlerde tanımlanan diğer birliklerin floristik yönden benzerlik oranları; Barla Dağı ile \%38, Seydişehir Maden Bölgesi ile \%24, Yandağ ile \%31, Dedegöl Dağı ile \%37'dir.

Cedrus libani birliği; Cedrus libani ormanları Akdeniz Dağ Katı'nda görülür. Genellikle 1500-2000 m'lerde yaygın olmasına rağmen bazı yerlerde 2200 ile 2300 m'ye kadar çıkarlar. Sicaklık bakımından Cedrus libani'nin alt kısımlara ait olanları soğuk, üst kısımlara ait olanları ise çok soğuk Akdeniz iklimine bağlanabilir. Batı ve güney Toroslarda Isparta'nın doğusunda yer alan ve Konya sınırları içine kadar uzanan Dedegöl (Anamas) Dağı'nda 1600-1800 m arasındaki kuzey yamaçlarda karaçamla karışık sedir ormanları mevcuttur (Serin, 1996). Seydişehir Maden Bölgesinde (Konya), 1600-1800 m arasında değişen yüksekliklerde Cedrus libani ormanları Abies cilicica ile karışık topluluklar meydana getirir (Ocakverdi, 1987).

Cedrus libani ormanları ilk defa Çetik (1976) tarafından fizyonomik görünüş bakımından sınıflandırılmıștır. Akman vd. (1978a) tarafından Querceta pubescentis sınıfının Querco-Cedretalia libani ordosu ve Abieto-Cedrion alyansına bağlanmıştır. Ermenek bölgesinde Vural vd. (1999) tarafından tespit edilen Abies cilicica subsp. isaurica ile karışık Abieto-Cedretum libani birliği Quercetea pubescetis sınıf, Querco-Cedretalia libani takımı ve Abieto-Cedrion alyansına dahil edilmiştir. Ayaşlıgil (1987), Köprüçay-Konglomerat, Alakırçay Birimi ve Mesozoik yaşlı anakayalardaki Cedrus libani birliklerini Abieto-Cedrion alyansı ve Querco-Cedretalia libani takımına bağlamıştır. Araştırma alanımıza çok yakın olan Barla Dağı'nda Bekat (1987) tarafından tanımlanan Cedrus libani ormanları ise Querco-Cedretalia libani takımı ve Lonicero-Cedrion alyansına bağlanmıştır. 
Sedir ormanları Torosların güney yönlerinde karaçam ormanlarının üst sınırlarında önemli yer işgal eder. Araştırma alanımızda bulunan Cedrus libani ormanları, Davras Dağı'nın doğusunda 15501650 m'ler arasında Acer hyrcanum subsp. sphaerocaryum ile karışık topluluklar meydana getirirler. $\mathrm{Bu}$ ormanlar Kovada Milli Parkı sınırları içinde yer aldığından çok iyi korunmuştur. Tanımlamış olduğumuz Veronico syriaci-Cedretum libani birliği Batı Toroslardaki Akdeniz Yüksek Dağ Katında yer alır. Birlik sintaksonomik olarak Quercetea pubescentis sinıfının Querco-Cedretalia libani ordosuna ve Lonicero cedrion alyansına bağlanmıştır. Bulgularımızla araştırma alanına yakın diğer Cedrus libani birliklerinin benzerlik oranları; Barla Dağı (Eğirdir) ile \%40, Dedegöl (Anamas) Dağı ile $\% 35$ 'dir.

Juniperus excelsa birliği; Anadolu'da 1000-2000 m arasında geniş bir yayılışa sahip olan Juniperus excelsa birliği, araştırma alanımızda üst Akdeniz vejetasyon katında yaygındır. Akman vd. (1979), Güney Anadolu'da yayılış gösteren Juniperus excelsa topluluklarını Querco-Cedretalia libani ordosuna dahil etmişlerdir. Ayaşlıgil (1987), Köprüçay-Konglomerat ve Mesozoik yaşlı anakayalarda yetişen Juniperus excelsa topluluklarının, Querco-Cedretalia libani ve Quercetalia pubescentis takımlarına ait karakter türleri içerdiklerini belirtmiş ve Quercetea pubescentis sınıfına bağlamıştır. Tanımlamış olduğumuz Minuartio globulosi-Juniperetum excelsae birliği, yıllık yağışın ortalama 550$800 \mathrm{~mm}$ arasında değiştiği kışı soğuk, az yağışlı Akdeniz ikliminin hüküm sürdüğü, anakayası kalker olan, erozyona uğramış taşlı ve sığ topraklarda yayılış gösterir. Birliğin Aliköy civarında bulunan kısmı yerleşim merkezine yakınlığından dolayı yıllardır kesim ve otlatma sebebiyle tahrip görmüştür. Ayrıca ağaç örtüşü çok fazla olmadığından floristik kompozisyonunda step karakterli türlerin sayısı oldukça çoktur. Bundan dolayı sözü edilen birliğin bitki sosyolojisi bakımından yorumu zor olmuştur. Birlik sintaksonomik olarak Quercetea pubescentis sinıfına ve Querco-Cedretalia libani ordosuna dahil edilmiştir. Bulgularımızla daha önce araştırma alanımıza yakın yerlerde tespit edilen Juniperus excelsa birliklerinin benzerlik oranları; Barla Dağı (Eğirdir) ile \%36, Yandağ (Isparta) ile \%27, Seydişehir Maden bölgesi ile \%17, Dedegöl Dağı ile \%32'dir.

Pinus brutia birliği; Anadolu'da geniş bir alanda yayılış gösteren Pinus brutia, Amanoslardan başlar bütün Toroslarda, Ege'nin batıya bakan kesimlerinde, ayrıca kuzey Anadolu'da Karadeniz bölgesinin güney kesimlerinde Karabük, Erbaa ve Samsun Alaçam bölgelerinde bulunur. Biyoiklim bakımından kızılçamlar, yağışı ve çok yağışı Akdeniz iklim katlarının sıcak, serin ve soğuk tiplerinde yayılış gösterirler. Pinus brutia'nın iklim ve toprak istekleri çok değişik olduğundan farklı bitki sosyolojisi birimlerine bağlanır. Türkiye'de ise iki değişik bitki sosyolojisi birimine bağlanır. Bunlardan Sicak ve Asıl Akdeniz katındaki kızılçamlar Quercetalia ilicis, Üst Akdeniz katındaki kızılçamlar Querco-Cedretalia libani ve Querco-Carpinetalia orientalis ordolarına bağlanır (Akman, 1990). Ayaşligil (1987), Antalya Köprülü Kanyon vejetasyonunda Pinus brutia birliklerinin Beşkonak ve Kırkkavak Formasyonları ve Alakırçay Birimi üzerindeki (130-1300 m'ler arasında) dağılımlarını inceleyerek, birlikleri Quercion calliprini alyansı ve Quercetalia (etea) ilicis sınıf ve takımı içinde değerlendirmiştir. Araştırma alanımızdaki Pinus brutia ormanları kışı soğuk, az yağışlı Akdeniz ikliminin etkisinde olup, 600-1000 m'ler arasında (Asıl Akdeniz Vejetasyon Katı) bulunur. Hyperico polyphylli-Pinetum brutiae birliğinin bitki sosyolojisi yönünden yorumlanması oldukça güçtür. Çünkü hem Quercetea ilicis hem de Quercetea pubescentis sınıflarına ait türler fazla miktarda bulunmaktadır. Fakat türlerin örtüş-sosyabilite değerleri ve tekerrür sınıfları dikkate alındığında birliğin Quercetea ilicis sinıfına, Quercetalia ilicis ordosuna ve Quercion cocciferae alyansina dahil edilmesi uygun görülmüştür. Birlik içinde ayrıca Pistacio-Rhamnetalia alaterni ordosuna ait türler de mevcuttur.

Quercus cerris birliği; Akman (1995), üst Akdeniz katının yaprak döken orman formasyonlarını coğrafik bakımdan üç bölgede değerlendirmiştir. Ege ve kuzeybatı Akdeniz'deki yaprak döken orman formasyonları, Orta ve kuzey Anadolu'daki yaprak döken ormanlar,Toros ve Amanos dağlarındaki yaprak döken ormanlar.

Ege ve kuzeybatı Akdeniz'de aşağı yukarı Aydın, Eskişehir ve Bolu' yu birleştiren bir çizginin batısında kalan bölgelerin tümünde üst Akdeniz katı yaprak döken ormanları, ormanlık alanın \%3040'ını oluşturur. Bu bölgede bulunan Quercus cerris ormanları Quercetea pubescentis sınıfı, Querco- 
Carpinetalia orientalis ordosu ve Carpino-Acerion alyansina dahil edilir (Akman vd., 1978a,b,c Ekim, 1991). Quercus cerris ormanları Suriye'nin kıyı bölgelerinde iyi gelişmiştir. Bu tür doğu Toroslarda bulunmakla beraber batı toroslarda bulunmaz. Buradaki Quercus cerris ormanları Querco-Cedretalia libani ordosuna, Abieto-Cedrion alyansına ve son zamanlarda yeni bir alyans olarak tanımlanan Ostryo-Quercion alyansına dahil edilir (Quézel vd., 1980). Tanımlamış olduğumuz birlik ise sintaksonomik olarak Quercetea pubescentis sinıfi ve Querco-Cedretalia libani ordosuna bağlanmıştır. Araştırma alanımıza yakın yerlerden Sultan dağlarında Ocakverdi ve Çetik (1982)'in tanımladığı Quercus cerris birliği ile tanımladığımız birliğin floristik benzerlik oranı \%26'dır.

Quercus vulcanica birliği; Karadağ'da orman vejetasyonunun en canlı örneği olan Quercus vulcanica, Başdağ'ın kuzey ve doğu yamaçlarında 1750-2000 m'lerde yaygındır. Oldukca gürbüz, sık ve $15 \mathrm{~m}$ boylanmıştır (Ocakverdi ve Ünal, 1991). Diantho cibrarii-Quercetum vulcanicae birliği, araştırma alanımızda 1350-1500 m'lerde, anakayası sert kalker olan ve asidik özellik taşıyan Kırmızı Kahverengi Akdeniz topraklarında yayılış gösterir. Birliğin dominant türü olan Quercus vulcanica araştırma alanımızda oldukça fazla örtüş ve sosyobiliteye sahiptir. Bu sebepten dolayı alt kısımlara yeterince güneş 1 şı̆̆ 1 alamaz ve buralardaki dallar kuruyarak dökülür. İnce gövdelerde boyuna uzamanın 25 m ‘ye kadar çıktığı görülür. Bu ender birlik Kovada Gölü Milli Parkı sınırları içerisinde yer aldığı için doğal hali oldukça iyi korunmuş olup adeta balta girmemiş orman niteliğindedir. Bu birlik, Kurt vd. (1996) tarafından araştırma alanımıza yapılan bir botanik gezisi esnasında daha önce tanımlanmıştır. Ayrıca Ocakverdi ve Ünal (1991) Karadağ’ da tanımlamış oldukları Quercus vulcanica birliğini, Quercetea pubescentis sinıfına, Querco-Carpinetalia orientalis ordosuna ve Quercion anatolicae alyansına bağlamışlardır. Araştırma alanımızdaki birlik ise Quercetea pubescentis sınıfı, Querco-Cedretalia libani ordosu ve Lonicero-Cedrion alyansına dahil edilmiştir.

Bulgularımız ile daha önce tanımlanan birliklerin benzerlik oranları; Karadağdaki birlik ile \%26, aynı bölgede daha önce Kurt vd. (1996) tarafından tanımlanan aynı birlikle \%43’tür. Aynı birlikler arasındaki bu benzerliğin düşük oranda çıkmasının nedeni iki çalışma arasında toplanan tür sayılarının farklı olmasıdır.

Quercus coccifera Birliği; Quercus coccifera (Kermes meşesi) Türkiye'de oldukça iyi gelişmiş olup, Akdeniz ve Ege bölgelerinin kıyı şeridinden başlar ve bu bölgelerin iç kısımlarına doğru geniş bir alana yayılır. Silifke'de Göksu vadisinde, Adana-Seyhan vadisinde ve doğu Toroslar'da 1300-1400 m yüksekliğe çıkarak sık topluluklar oluşturur. Bu tür batı ve güney Anadolu'da step öncesi Akdeniz katına kadar sokulmaktadır (Akman, 1995). Araştırma alanımızdaki Quercus coccifera birliğinin bünyesinde yüksek oranda step bitkisinin bulunması bunu doğrulamaktadır. Biyoiklim bakımından kserofil meşe toplulukları yarı kurak, az yağışlı ve yağışı Akdeniz katında bulunur. Buna göre Maraş-Gaziantep dolaylarındaki bazı topluluklar yarı kurak; Toros dağlarındaki ekseri topluluklar ise yağışlı ve az yağışlı biyoiklim katına girer. Araştırma alanımızdaki birlik ise yarı kurak, kışı soğuk, az yağışlı Akdeniz biyoiklim katında gelişir. Yurdumuzda kserofil meşe toplulukları genellikle Quercion cocciferae ve Quercion ilicis alyanslarına bağlanır. Quercion cocciferae alyansına bağlanan kserofil meşeler güney ve güneybatı Anadolu'da 300-1000 m'lerde iyi gelişmiştir. Quercion ilicis alyansına bağlananlar ise, Ege, Marmara ile orta ve bat1 Toroslar'da Antalya-Beşkonak civarında 200-1250 m'lerde iyi gelişmiştir (Akman, 1995). Araştırma alanımıza yakın olan Barla Dağı'nda Bekat (1987) ve Dedegöl (Anamas) Dağı'nın doğu kısmında Serin (1996) tarafından tanımlanan Quercus coccifera birliği, Quercetea pubescentis sınıfı ve Querco-Cedretalia libani ordosu'na bağlanmıştır. Kargığlu ve Tatlı (1994) Yandağ' da tanımlamış olduğu Quercus coccifera birliğini Quercetea (etalia) ilicis sınıf ve ordosuna dahil etmişlerdir.

Tanımlamış olduğumuz birlik, Batı Toroslarda üst Akdeniz vejetasyon katında, anakayası sert kalker olan organik madde bakımından fakir topraklarda 1050-1500 m'lerde yayılış gösterir. Birlik, Quercetea pubescentis sınıfı ve Querco-Cedretalia libani ordosu'na dahil edilmiştir. Araştırma alanına yakın yerlerde tanımlanan Quercus coccifera birlikleri ile bulgularımız arasındaki benzerlik oranları; Yandağ ile \%51, Barla dağı ile \%33, Dedegöl dağı ile \%37'dir. Yandağ'ın araştırma 
alanımıza sınır olması ve floristik benzerliğin oldukça fazla olması, burada tanımlanan birliğin tanımladığımız birlik ile aynı birlik olduğu kanaati oluşturmuştur.

Astragalus microcephalus birliği; İç Anadolu Bölgesi'nin muhtelif yerlerinde iyi araştırılmıştır. Ayaş dağlarında 900 ile 1300 m yüksekliler arasında yumuşak marnlı veya volkanik ana kayalar üzerindeki AC profilli, kalkerli veya kalkersiz kaba erozyon toprakları üzerinde gelişmektedir (Davis, 1965-1985). Daha önce Ocakverdi ve Ünal (1991) tarafından Karadağ’da, Tatlı vd. (1994) tarafından Kızılören, Çal ve Loras Dağları'nda tanımlanmış olan Astragalus microcephalus birliği, Astragalo-Brometea sinifina, Onobrychido armeni-Thymetalia leucostomi ordosuna ve Phlomido armeniaca-Astragalion microcephali alyansına dahil edilmiştir.

Araştırma alanımızda tanımlamış olduğumuz Astragaletum prusiano-microcephali birliği, yüksek kireç içeriğe sahip ana madde üzerinde oluşmuş kahverengi orman topraklarında, ayrıca ana maddesi volkanik tüf ve kül olan Regosol Topraklar üzerinde yüksekliği 1450-1700 m'ler arasında değişen alanlarda yayılış göstermektedir. Birlik, sintaksonomik olarak Astragalo-Brometea sınıfına, Onobrychido armeni-Thymetalia leucostomi ordosuna ve Phlomido armeniaca-Astragalion microcephali alyansına dahil edilmiştir. Araştırma alanına yakın yerlerde tanımlanan Astragalus microcephalus birliklerinin bizim tanıladığımız birlik ile floristik kompozisyon bakımından benzerlik oranları: Karadağ'da tanımlanan birlik ile \%30, Kızı̈ören, Çal ve Loras Dağları'nda tanımlanan birlik ile \%40'tır. Isparta'nın güney batısında Regosol topraklarda yayılış gösteren Astragalus microcephalus toplulukları oldukça fazla örtüşe sahiptir ve dik yamaçlarda erozyonu önleyen en önemli unsurdur.

Daphne oleoides birliği; Astragalo heldreichii-Daphnetum oleoidis birliği, araştırma alanımızda Davras Dağı'nın batı ve güneybatıya bakan yamaçlarında kalker anakayadan oluşmuş Kırmızı Akdeniz Toprakları üzerinde yayılış gösterir. Birliğin yayılış gösterdiği alanların eğimi $30^{\circ}$ $50^{\circ}$ ve yüksekliği 2020-2300 m'ler arasında değişir. Birliğin bulunduğu yüksekliğe ve bünyesindeki bitkilere bakıldığı zaman diğer step birliklerinden farklı olarak yüksek dağ stebi birliği özelliği taşır. Rakım 2020 m'den yukarı doğru çıktıkça eğim artmakta ve topraklar azalarak yerini yer yer hareketli kayalara bırakmaktadır. Örtüş yüzdesi azalsa da birlik bu şekilde 2350 m'ye kadar çıkmaktadır. Böylece step bitkilerinin arasına kaya vejetasyonuna ait Asplenietea trichomanis sınıfı ve Silenetalia odontopetalae ordosunun karakterleri de sokulmaktadır. Birlik sintaksonomik olarak AstragaloBrometea sınıfına ve bu sınıfa bağlı Drabo-Androsacetalia ordosuna bağlanmıştır.

Omphalodes luciliae birliği; Aubrieto canescentis-Omphalodetum luciliea birliği, araştırma alanımızda Davras Dağı'nın batı ve güneybatıya bakan kalker kayalıklarında yayılış gösterir. Birliğin, uçurum kayalıkların çatlakları ve çukurları arasında birikmiş topraklar üzerinde gelişmiş olan bitkilerinin tamamı otsu formdadır. Birlik, batı Toroslardaki yüksek dağların kaya birliklerini içine alan Asplenietea trichomanis sınıfına, Silenetalia odontopetalae ordosuna ve Silenion odontopetalae alyansına dahil edilmiştir.

\section{Teşekkür}

Bu çalışmada Selçuk Üniversitesi Bilimsel Araştırma Projeleri Fon Müdürlüğü Tarafından 2002/18 nolu proje ile desteklenen doktora tezinden faydalanılmıştır. Desteklerinden dolayı Selçuk Üniversitesi Bilimsel Araştırma Projeleri Fon Müdürlügü’ne teşekkür ederim.

\section{Kaynaklar}

Akman, Y., Barbéro, M., Quézel, P. 1978a. Contribution a l'étude de végétation foresitiére d'Anatolie Méditerranéenne. Phytocoenologia, 5 (1): 1-79.

Akman, Y., Barbéro, M., Quézel, P. 1978b. Contribution a l'étude de végétation foresitiére d'Anatolie Méditerranéenne. Phytocoenologia, 5 (2): 189-276.

Akman, Y., Barbéro, M., Quézel, P. 1978c. Contribution a l'étude de végétation foresitiére d'Anatolie Méditerranéenne. Phytocoenologia, 5 (3): 277-346. 
Akman, Y., Barbéro, M., Quézel, P. 1979. Contribution a l'étude de végétation foresitiére d'Anatolie Méditerranéenne. Phytocoenologia, 5 (3): 277-346.

Akman, Y., Ketenoğlu, O., Quézel, P. 1985. A new Syntaxon from Central Anatolia. Ecologia Mediterranea, 11 (2/3): 111-121.

Akman, Y. 1990. İklim ve Biyoiklim. Palme Yayın Dağıtım, Ankara.

Akman, Y. 1995. Türkiye Orman Vejetasyonu. Ankara.

Anonim, 1994. Köy Hizmetleri Genel Müdürlüğü. Isparta İli Arazi Varlı̆̆ı. İl rapor no. 32, Ankara.

Anonim, 2002. Meteoroloji Bölge Müdürlüğü. Araştırma ve Bilgi İşlem Dairesi Başkanlığı, Isparta.

Avcı, M. 1991. Göller Yöresi Batı Kesiminin Bitki Coğrafyası. İstanbul Üniversitesi Sosyal Bilimler Enstitüsü, Basılmamış doktora tezi, İstanbul.

Avcı, M. 1993-1996a. Göller yöresi batı kesiminde bitki toplulukları ve dağıllışları. İstanbul Üniversitesi Edebiyat Fakültesi Coğrafya Bölümü Coğrafya Dergisi, 4: 227-264.

Avcı, M. 1993-1996b. Göller yöresi batı kesiminde iklim özellikleri ile bitki örtüsü arasındaki ilişskiler. İstanbul Üniversitesi Edebiyat Fakültesi Coğrafya Bölümü Coğrafya Dergisi, 4: 143215.

Avc1, M. 1996. Endemik bir meşe türü, kasnak meşesi (Quercus vulcanica (Boiss. Heldr. ex) Kotschy)'nin Türkiye'deki yeni bir yayılış alanı. Türk Coğrafya Dergisi, 31: 283-289.

Ayaşlıgil, Y. 1987. Der Köprülü Kanyon Nationalpark, Seine Vegetation und ihre Beeinflussung durch den Menschen. Landschaftsökologie, Weihenstephan, Hefts, München, German.

Barbéro, M., Quézel, P. 1979. Le probléme dés manteaux forestiers des Pistacio-Rhamnetalia dans les foréts de Méditerraneé orientale. Coll. Phytosoc. Lille, 8: 9-21.

Bekat, L. 1987. Barla Dağı'nın (Eğirdir) Vejetasyonu. Doğa Türk Botanik Dergisi, 11 (3): 270- 305.

Braun-Blanquet, J. 1932. Plant Sociology (Translated By Fuller and Conard). Mc Graw-Hill, New York and London.

Braun-Blanquet, J. 1964. Pflanzensoziologie, Grundzüge der Vegetationskunde, 3. Aufl. Springer Verlag, Wien and New York.

Bray, J.R. and Curtis, J.T. 1957. An Ordination of the upland forest communities of soutern Wisconsin. Ecological Monographs, 27: 325-49.

Çetik, R. 1976. The Phytosociological and Ecological Studies of the Cedrus Woodland Vegetation of the Çığlıkara, Bucak and Elmalı. Com de la Fac. Sc. I'Univ d'ankara, Serie C2, Tome 20.

Davis, P.H. (ed.) 1965-1985. Flora of Turkey and the East Aegean Islands. Vol. 1-9. Edinburgh.

Davis, P.H., Mill, R.R., Tan, K. (eds.) 1988. Flora of Turkey and the East Aegean Islands. Vol. 10. Edinburgh.

Ekim, T., Akman, Y. 1991. Eskişehir ili Sündiken dağlarındaki orman vejetasyonunun bitki sosyolojisi bakımından araştırılması. Doğa Turkish Journal Of Botany, 15 (1): 28-40.

Gemici, Y., Görk, G., Acar, İ. 1994. Batı ve Güney Anadolu Yüksek Dă̆ Vejetasyonu. Tübitak, TBAG-993, 207 sayfa, Ankara.

Geven, F., Ketenoğlu, O., Bingöl, Ü., Güney, K. 2009. İç Anadolu'dan (Polatl1-Haymana) Astragalo karamasici-Gypsophilion eriocalycis Alyansı için Yeni Sintaksonlar. Ekoloji 18 (71): 32-48.

Gezer, A., Bilir, N., Gülcü, S. 2001. Kasnak Meşesi [( Quercus vulcanica Boiss. and Heldr. ex) Kotschy] Meyve ve Fidanlarının Bazı Özellikleri Üzerine Araştırmalar. Süleyman Demirel Üniversitesi Orman Fakültesi Dergisi, 2: 1-10.

Güner, A., Özhatay, N., Ekim, T., Başer, K.H.C. (eds.) 2000. Flora of Turkey and East Aegean Islands, Vol. 11, Edinburgh.

Hein, P., Kürschner, H., Parolly, G. 1998. Phytosociological studies on high mountain plant communities of the Taurus Mountains (Turkey). 2. Rock communities. Phytocoenologia, 28: 465-563. 
Kargıŏlu, M., Tatlı, A. 2005. A Phytosociological Research on the Forest Vegetation of Yandağ (Isparta-Turkey). Pakistan J. of Biological Sciences, 8 (6): 929-939.

Ketenoğlu, O., Kurt, L., Akman, Y., Serin, M. 1996. A new alliance from Central Anatolia., "Minuartion Juniperino-pestalozzae". Turkish Journal of Botany, 20: 457-464.

Kurt, L., Akman, Y., Quézel, P., Ekim, T., Demiryürek, E. 1996. Etude Synécologique des forést de Quercus vulcanica des environs d'Isparta-Eğirdir Turquie. Ecologia Mediterranea, 22 (3/4): 53-57.

Ocakverdi, H., Çetik, R. 1982. Sultan Dağları Doğanhisar (Konya) Bölgesinin Fitososyolojik ve Fitoekolojik Yönden İncelenmesi. Ankara Üniversitesi Fen-Edebiyat Fakültesi Fen Dergisi, 2: 73-90.

Ocakverdi, H. 1987. Seydişehir Maden Bölgesi (Konya) ve Çevresinin Vejetasyonu. Türk Botanik Dergisi, 11 (1): 120-128.

Ocakverdi, H., Ünal, A. 1991. Karadağ'nn (Karaman) Bitki Sosyolojisi ve Ekolojisi Yönünden İncelenmesi. Doğa Turkish Journal of Botany, 15: 79-100.

Parolly, G. 1998. Phytosociological studies on high mountain plant communities of the South Anatolian Taurus Mountains. 1. Scree plant communities (Heldreichietea): A synopsis. Phytocoenologia, 28: 233-284.

Parolly, G. 2004. The High Mountain Vegetation of Turkey-a State of the Art Report, Including a First Annotated Conspectus of the Art Report, Including a First Annotated Conspectus of the Major Syntaxa. Turkish Journal of Botany 28: 39-63.

Quézel, P. 1973. Contribution a I'Etude phytosociologique du Massif du Taurus. Phytocoenologia 1, 2, 131-122.

Quézel, P., Barbéro, M., Akman, Y. 1978. L’interpretation Phytosociologique des Groupements Forestière Dans le Bassin Méditerraneén Orientale, Documents Phytosociologiques N. S. 2: 329-352.

Quézel, P., Barbéro, M., Akman, Y. 1980. Contribution a I'Etude de la végétation forestiére d'Anatolie Septenrionale. Phytocoenologia, 8 (3): 365-519.

Quézel, P., Barbéro, M., Akman, Y. 1992. Typification de Syntaxa Décrits en Region Méditerranéenne Orientale. Ecologia Mediterranea, 18: 61-87.

Sağlam, C. 2007. Davras Dağı (Isparta ) ve Çevresinin Orman ve Çalı Vejetasyonu. Süleyman Demirel Üniversitesi Fen Bilimleri Enstitüsü Dergisi, 11 (2): 140-157.

Sağlam, C. 2007. Davras Dağı (Isparta ) ve Çevresinin Step ve Kaya Vejetasyonu. Dumlupınar Üniversitesi Fen Bilimleri Enstitüsü Dergisi, 14: 11-25.

Serin, M. 1996. Dedegöl (Anamas) Dağının Doğu Kısmı ile Kurucuova-Yeşildağ (Beyşehir-Konya) ve Çevresinin Vejetasyonu. Selçuk Üniversitesi Fen Dergisi, 13: 28-49.

Sorensen, T.A. 1948. A method at estabilishing groups of equal amplitude in plant sociology based on similarity of species content and its application to analyses of vegetation of Danish commons. Biologiske Skrifter Kongelige Danske Videnskabernes Selskab, 5 (4): 1-34.

Şenel, M. 1997. 1/100.000 Jeoloji Haritası. T. C. MTA Genel Müdürlüğü, Ankara.

Tatlı, A., Eyce, B., Serin, M. 1994. Kızılören, Çal ve Loras Dağları (Konya) Vejetasyonu. Turkish Journal Of Botany, 18: 167-288.

Van der Maarel, E. 1979. Transformation of cover-abundance values in phytosociology and its effects on community similarity. Vegetatio 39: 97-144.

Vural, M., Akman, Y., Qézel, P. 1999. Contribution a l'étude de la vegetation forestiére du Taurus central: analyse phyto-écologique d'un transect sud-nord, entre Silifke et Karaman. Phitosociologia, 36 (1): 3-21.

Weber, H.E., Moravec, J., Theurillat, J.P. 2000. International Code of Phytosociological Nomenclature. 3rd edition. Journal of Vegetation Science 11: 739-768.

Zohary, M., 1973. Geobotanical Foundations of Middle East. Vol:1-2 Gustov Fischer VerlagStuttgart. 